\title{
Current views on cell metabolism in SDHx-related pheochromocytoma and paraganglioma
}

\author{
Ales Vicha, David Taieb ${ }^{1,2}$ and Karel Pacak ${ }^{3}$ \\ Department of Pediatric Hematology and Oncology, 2nd Medical School, Charles University and University Hospital \\ Motol, Prague, Czech Republic \\ ${ }^{1}$ Service Central de Biophysique et de Médecine Nucléaire, CERIMED Centre Hospitalo-Universitaire Timone, \\ Marseille, France \\ ${ }^{2}$ Département d'Oncologie Moléculaire, Centre de Recherche en Cancérologie de Marseille, Marseille, France \\ ${ }^{3}$ Program in Reproductive and Adult Endocrinology, Eunice Kennedy Shriver National Institute of Child Health and \\ Human Development (NICHD), National Institutes of Health, Building 10, CRC, 1-East, Room 1-3140, 10 Center Drive, \\ MSC-1109, Bethesda, Maryland 20892-1109, USA
}

\author{
Correspondence \\ should be addressed \\ to K Pacak \\ Email \\ karel@mail.nih.gov
}

\begin{abstract}
Warburg's metabolic hypothesis is based on the assumption that a cancer cell's respiration must be under attack, leading to its damage, in order to obtain increased glycolysis. Although this may not apply to all cancers, there is some evidence proving that primarily abnormally functioning mitochondrial complexes are indeed related to cancer development. Thus, mutations in complex II (succinate dehydrogenase (SDH)) lead to the formation of pheochromocytoma (PHEO)/paraganglioma (PGL). Mutations in one of the SDH genes (SDHx mutations) lead to succinate accumulation associated with very low fumarate levels, increased glutaminolysis, the generation of reactive oxygen species, and pseudohypoxia. This results in significant changes in signaling pathways (many of them dependent on the stabilization of hypoxia-inducible factor), including oxidative phosphorylation, glycolysis, specific expression profiles, as well as genomic instability and increased mutability resulting in tumor development. Although there is currently no very effective therapy for SDHx-related metastatic PHEOs/PGLs, targeting their fundamental metabolic abnormalities may provide a unique opportunity for the development of novel and more effective forms of therapy for these tumors.
\end{abstract}

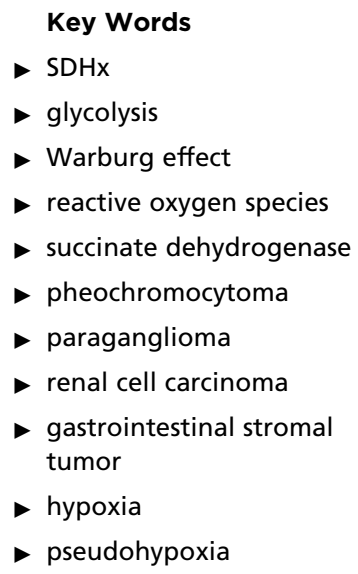

Endocrine-Related Cancer (2014) 21, R261-R277

\section{Introduction}

In previous innovative work, Hanahan \& Weinberg (2000) determined the unique hallmarks of cancer that together constitute a fundamental principle that provides a logical framework for understanding the remarkable diversity, yet nevertheless similarity, of various cancers. Six hallmarks of cancer, namely sustaining proliferative signaling, evading growth suppressors, activating invasion and metastasis, enabling replicative immortality, promoting angiogenesis, and resisting cell death, are the driving forces that ultimately cause cancer cell development and spread, leading to patient death (Hanahan \& Weinberg 2000). Recently, Hanahan \& Weinberg (2011) have added two new emerging hallmarks: evading immune destruction and reprograming energy metabolism.

Additional scientific studies have also shown that altered energy metabolism is as widespread in cancer cells as many of the other cancer-associated traits that have been well accepted as the hallmarks of cancer

Published by Bioscientifica Ltd 
(Levine \& Puzio-Kuter 2010). This raises the question of whether deregulating cellular energy metabolism could be a core hallmark of cancer cells. In fact, redirection of energy metabolism is largely orchestrated by proteins that are involved in one way or another in programing the core hallmarks of cancer. When viewed in this way, abnormal oxidative phosphorylation (OXPHOS) is simply another phenotype that is caused by altered oncogenes or tumor suppressor genes (Levine \& Puzio-Kuter 2010). Multiple lines of evidence indicate that the process of tumorigenesis is often associated with altered metabolism. In 1926, Otto Warburg reported that cancer cells produce most of their ATP via 'aerobic glycolysis' (Warburg et al. 1926). A significant glycolytic production of ATP despite aerobic conditions, referred to as the Warburg effect, was found to be the characteristic of most cancer cells (Warburg 1956). Warburg reasoned that respiration must be damaged in cancers because high levels of $\mathrm{O}_{2}$ are unable to suppress the production of lactic acid by cancer cells (known as the Pasteur effect). However, new studies have demonstrated that tumor mitochondria are fairly functional with regards to respiration and ATP synthesis, exhibiting almost normal respiratory control ratios and capabilities for the oxidation of respiratory substrates (Eakin et al. 1972, Bensinger \& Christofk 2012, Krejci 2012, Nakajima $\&$ Van Houten 2013).

Although mitochondria are fairly functional in the majority of cancers, some cancers were found with mutations in the genes linked to paramout mitochondrial processes, the Krebs cycle (tricarboxylic acid cycle (TCA); Linehan \& Rouault 2013, Zhang et al. 2013) and OXPHOS. Mitochondrial complex II, also known as succinate dehydrogenase $(\mathrm{SDH})$, is one such protein involved in both TCA and OXPHOS. This membrane complex catalyzes the oxidation of succinate to fumarate in TCA and serves as an electron donor to complex III via CoQ (Eng et al. 2003, Gottlieb \& Tomlinson 2005). Succinate oxidation results in the reduction of ubiquinone (CoQ) to ubiquinol at the mitochondrial inner membrane as one part of the respiration electron transfer chain (Sun et al. 2005a). SDH is composed of four subunits (SDHA-D), all encoded by nuclear genes (Baysal 2003, 2008, Yankovskaya et al. 2003, Sun et al. 2005b, Cascon et al. 2008). The large SDHA subunit is catalytic. The conversion of succinate to fumarate is accomplished by SDHA through the reduction of a flavin adenine dinucleotide, a molecule bound to its protein moiety. This reaction is measured as SDH activity. Electrons are then passed to three Fe-S centers bound to SDHB, which eventually transfers them to ubiquinone (coenzyme $\mathrm{Q}$ ). The smaller subunits, SDHC and SDHD, bind ubiquinone and anchor the entire complex to the inner membrane of the mitochondria (Rustin et al. 2002).

Deleterious mutations in any of the $S D H$ genes invariably result in decreased SDH activity or a significant reduction or complete absence of the protein (Rustin et al. 2002, van Nederveen et al. 2009, Gill et al. 2011, Korpershoek et al. 2011, Yang et al. 2012). Inherited defects in particular SDH subunits in humans are associated with variable clinical presentations ranging from early-onset devastating encephalomyopathy to tumor susceptibility or optic atrophy. Homozygous or compound heterozygous mutations in SDHA cause metabolic neurodegenerative disorders like congenital Leigh syndrome and late-onset optic atrophy, ataxia, and myopathy (Birch-Machin et al. 2000, Parfait et al. 2000, Horvath et al. 2006, Burnichon et al. 2010, Levitas et al. 2010). Recently, Alston et al. (2012) have presented the first patient with hypotonia and leukodystrophy due to a novel homozygous $S D H B$ mutation. Heterozygous mutations in SDHA-D predispose to tumorigenesis (Fig. 1; Maher \& Eng 2002, Astuti et al. 2003, 2004, Eng et al. 2003, Schiavi et al. 2005, Bayley et al. 2006, Benn et al. 2006, Cascon et al. 2008). The detailed molecular and cellular mechanisms linking these latter SDH mutations and tumorigenesis have not been fully elucidated. Thus, consistent with Knudson's two-hit hypothesis for tumorigenesis, a heterozygous germline mutation in an $S D H$ gene is associated with a loss of the WT allele, or other silencing mechanisms (e.g. methylation) of the WT allele are present in a tumor (Baysal et al. 2000, Astuti et al. 2003, 2004, Baysal 2003, 2004, 2008, Eng et al. 2003, Gimenez-Roqueplo et al. 2003, Ni et al. 2008, 2012, Sandgren et al. 2010, Bardella et al. 2011, Killian et al. 2013, Letouze et al. 2013) as the starting point for tumor development. Moreover, the pathophysiology of distinct clinical phenotypes associated with abnormalities in SDH subunits remains to be determined (Timmers et al. 2009a). Detailed knowledge about SDH mutations is available in a database (LOVD, v.2.0 (Leiden Open Variation Database), http://www.lovd.nl/2.0; Bayley et al. 2005).

Although these findings led to a renewed interest in cancer metabolism, our knowledge on the specifics of tumor metabolism is still fragmented. Nevertheless, multiple lines of evidence indicate that the process of tumorigenesis is often associated with altered metabolism. In this review, we show and discuss how mutations in $S D H$ subunits can lead to reprograming of cancer-related metabolism. Also, this paper reviews recent findings

Published by Bioscientifica Ltd. 


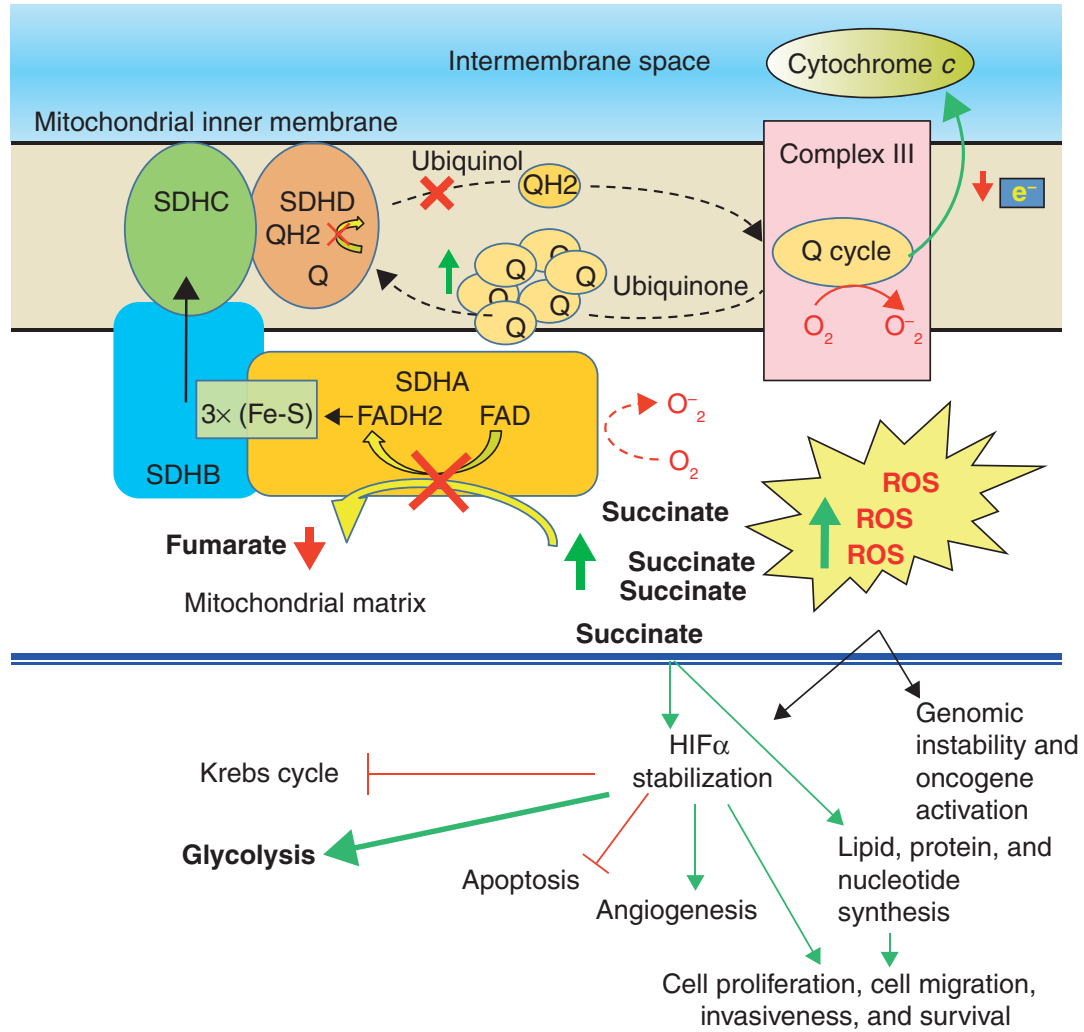

\section{Figure 1}

The succinate dehydrogenase complex (SDH), as a member of the tricarboxylic acid cycle (TCA), catalyzes the oxidation of succinate to fumarate. In this reaction, two hydrogen atoms are removed from succinate by FAD. These electrons from the reduced SDH-FADH $\mathrm{H}_{2}$ complex are then transferred to ubiquinol-ubiquinone (coenzyme Q), a soluble component of the electron transport system of complex II. In the Q cycle, the sequential oxidation and reduction of the lipophilic electron carrier, coenzyme Q, generates protons that are transferred to complex III, with the ultimate generation of ATP (complex V). Coenzyme Q, beside its function in the respiratory chain as an electron carrier mediating electron transfer between the various dehydrogenases and the cytochrome pathway, also works as a powerful antioxidant in biological membranes.

related to key metabolites, transcription factors, and enzymes that play an important role in the regulation of cancer metabolism, and that blocking these metabolic pathways or restoring altered pathways can lead to new approaches in cancer treatment.

\section{Pheochromocytoma and paraganglioma}

Pheochromocytomas (PHEOs)/paragangliomas (PGLs) are rare neuroendocrine tumors that produce catecholamines (Lenders et al. 2005). PHEOs/PGLs arise from three distinct parts of the neural crest: the adrenal medulla (PHEOs) and the sympathetic and parasympathetic paraganglia (extradrenal PGLs) (Papaspyrou et al. 2012).
Dysfunction of SDH inactivates the electron transport chain and the Krebs cycle. A lack or suboptimal level of SDH activity will not only cause decreased ATP production, but will also result in increased ROS with succinate accumulation. An increase in ROS, like the accumulation of succinate, leads to stabilization of HIF $\alpha$. HIF $\alpha$ stabilization subsequently activates glycolysis, cell proliferation, cell migration, invasiveness, and angiogenesis and inhibits apoptosis. The overexpression of ROS triggers genomic instability, oncogene activation, and tumor suppressor inactivation. $\mathrm{e}^{-}$, electron; $F A D$, flavin adenine dinucleotide; $\mathrm{FADH}_{2}$, FAD hydroquinone; ROS, reactive oxygen species; $Q$, ubiquinone; $\mathrm{QH} 2$, ubiquinol; SDHA, B, C, and D, succinate dehydrogenase complex subunits $A, B, C$, and $D$.

One-third or more of PHEO/PGL cases have a familial etiology (Neumann et al. 2002, Erlic et al. 2009, GimenezRoqueplo et al. 2012). This group is heterogeneous with diverse hereditary backgrounds due to germ line mutations in 16 susceptibility genes to date. Some of these include neurofibromatosis type 1 (NF1; Viskochil et al. 1990), the ret proto-oncogene (RET; Mulligan et al. 1993), the von Hippel-Lindau (VHL; Latif et al. 1993) tumor suppressor, the $S D H$ subunits $(S D H A / B / C / D$; Baysal et al. 2000, Niemann \& Muller 2000, Astuti et al. 2001, Burnichon et al. 2010), SDH complex assembly factor 2 (SDHAF2; Hao et al. 2009), transmembrane protein 127 (TMEM127; Qin et al. 2010, Yao et al. 2010, Jiang \& Dahia 2011), the MAX protein (MAX; Comino-Mendez et al. 2011), kinesin

Published by Bioscientifica Ltd. 
family member 1B (KIF1B; Schlisio et al. 2008, Yeh et al. 2008), the 2-oxoglutarate (2OG)-dependent prolyl hydroxylase enzymes (PHD2, Ladroue et al. 2008, Eltzschig et al. 2009), isocitrate dehydrogenase 1 (IDH1; Gaal et al. 2010), and most recently hypoxia-inducible transcription factor 2 $\alpha$ (HIF2A; Zhuang et al. 2012, Toledo et al. 2013), fumarate hydratase (FH; Castro-Vega et al. 2013), and H-RAS protein (H-RAS; Crona et al. 2013). Somatic mutations of these genes are also involved in PHEO/PGL tumors (Burnichon et al. 2012a, Weber et al. 2012, Crona et al. 2013, Dahia 2013). Hereditary and sporadic PHEOs/PGLs can be divided into two groups based on their transcription profile revealed by genome-wide expression microarray analysis (Lopez-Jimenez et al. 2010, Burnichon et al. 2011, Galan \& Kann 2013, Vicha et al. 2013). The first group (cluster 1) includes tumors carrying VHL and SDHX (SDHD, SDHB, SDHC, SDHA, and SDHAF2) mutations and also accounts for about $30 \%$ of sporadic tumors (Dahia et al. 2005, Lopez-Jimenez et al. 2010, Burnichon et al. 2011). The second group (cluster 2) represents tumors carrying $N F 1, R E T$, and KIF1B $\beta$ mutations, and also includes about $70 \%$ of sporadic tumors (Burnichon et al. 2011, Gimenez-Roqueplo etal. 2012, Shah et al. 2012, Galan \& Kann 2013). The newly discovered TMEM127 and MAX genes are most likely associated with cluster 2, and HIF2 $\alpha$ with cluster 1 (Burnichon et al. 2011, 2012b, Lorenzo et al. 2012, Zhuang et al. 2012). However, a subset of MAX-related tumors may have impaired SDH activity, and metabolomics in these tumors could uncover new data that could be very useful clinically for their diagnosis (Rapizzi et al. 2012).

In cluster $1, V H L / S D H x$ mutations lead to impaired degradation and accumulation of HIF $1 / 2 \alpha$ and display signatures of pseudohypoxia, angiogenesis, increased reactive oxygen species (ROS), and reduced oxidative response resulting in changes in cell metabolism (energy metabolism regulation). $V H L$ and $S D H$ subunit mutations distribute tumors to separate subclusters within cluster 1 (Eisenhofer et al. 2004, Dahia et al. 2005, Burnichon et al. 2009, Lopez-Jimenez et al. 2010). Cluster 2-related PHEOs/PGLs are linked together by the activation of kinase signaling pathways driven by oncogenes that are involved in kinase signaling, translation, initiation, protein synthesis, and genes involved in neural/neuroendocrine identity (Dahia et al. 2005, Powers et al. 2007, Yeh et al. 2008, Burnichon et al. 2011, Jiang \& Dahia 2011, Shah et al. 2012). Cluster 1 is characterized by immature catecholamine phenotypic features of associated tumors (Eisenhofer et al. 2004). The immature phenotype involves reduced or absent expression of numerous catecholamine biosynthetic and secretory pathway components, mainly phenylethanolamine $N$-methyltransferase, the enzyme that converts norepinephrine to epinephrine (Eisenhofer et al. 2011a, 2012). Also, SDH-related tumors often produce dopamine. Thus, cluster 1 tumors can be distinguished from cluster 2 tumors by the absence of epinephrine production (Eisenhofer et al. 2004, 2011a,b, Burnichon et al. 2012b, Eisenhofer et al. 2012). Most recently, Imperiale et al. (2013) evaluated metabolic characteristics of PHEOs/PGLs tumors, using ${ }^{1} \mathrm{H}$ highresolution magic angle spinning nuclear magnetic resonance (HRMAS-NMR) spectroscopy. $S D H x$-related tumors were characterized by an increase in succinate levels, significantly lower values of glutamate, and lower values of ATP/ADP/AMP in $S D H x$-related tumors compared with other subtypes. VHL tumors were found to have the highest values of glutathione (GSH) compared with other PHEOs/PGLs. This study showed that HRMAS-NMR spectroscopy is a future promising method for investigating the metabolomic profile of various PHEOs/PGLs.

\section{SDH dysfunction and metabolic changes}

\section{Succinate accumulation}

It is well documented that abnormal SDH function induces an accumulation of succinate (Selak et al. 2005, King et al. 2006, Hobert et al. 2012, Rao et al. 2013). Very recently, Lendvai et al. (2013) showed that tissue levels of succinate in PGLs due to $S D H B / D$ mutations were severalfold higher. Their results showed that the mean fumarate concentration in SDHB-related PGLs is significantly lower than in the apparently sporadic PHEO/PGL group. Lendvai et al. (2013) also demonstrated a significantly increased succinate:fumarate ratio in $S D H B$-related PGLs and suggested that this ratio may be used as a new metabolic marker for the detection of $S D H B$-related PHEOs/PGLs. Thus, mass spectrometric-based measurements of succinate:fumarate ratios in PHEO/PGL tumor tissue may provide a novel method to identify patients to be tested for SDHB/C/D mutations. The measurements could also be useful for assessing metabolic factors responsible for variable clinical presentations of tumors resulting from mutations of different SDHx genes. Also, plasma organic acid analysis may provide an effective and inexpensive screening method to determine the presence of $S D H x$ mutations in the near future (Hobert et al. 2012).

The accumulation of specific metabolites has been illustrated in different tumor models with inherited and acquired alterations of enzymes of the TCA cycle, such as

Published by Bioscientifica Ltd. 
fumarate in cases of $F H$ gene mutations (Isaacs et al. 2005) and 2-hydroxyglutarate in mutations in one of the two IDH genes (IDH1/2) (Dang et al. 2009). These findings have important implications for our understanding of tumorigenesis because these metabolites convey oncogenic signals (oncometabolites; Kaelin \& McKnight 2013).

Succinate that accumulates in the mitochondrial matrix due to SDH dysfunction leaks out into the cytosol, where it inhibits the activity of HIF1/2 $\alpha$ PHDs (PHD1, 2, and 3, also known as EGLN2, 1, and 3 respectively) that hydroxylate two prolyl residues (Dann \& Bruick 2005). PHDs are members of a large superfamily of $\alpha$-ketoglutarate-dependent dioxygenases. PHD action normally requires oxygen and $\alpha$-ketoglutarate as cosubstrates and ferrous iron and ascorbate as cofactors. (Hewitson et al. 2003, Kaelin \& Ratcliffe 2008). Succinate competes with $\alpha$-ketoglutarate in binding to the PHD enzyme. Therefore, increasing succinate levels offset the effect of PHD activity. A lack of SDH activity inhibits succinate-ubiquinone activity; thus, electrons that would normally transfer through the SDHB subunit to the ubiquinone pool are instead donated to molecular oxygen to give a superoxide anion with a subsequent increase in ROS production and oxidative stress. ROS exposure also inhibits the interaction of HIF $\alpha$ and PHDs, similar to the accumulation of succinate, but it is proposed that such an inhibition of this interaction by ROS may be more important for tumorigenesis (Yankovskaya et al. 2003, Guzy et al. 2008, Majmundar et al. 2010). The inhibition of the HIF $\alpha$-PHD interaction leads to the stabilization of HIF $\alpha$ and activation of the HIF complex (Lee et al. 2005). $\mathrm{HIF} \alpha$ regulates the transcription of a number of genes that are known to be involved in tumorigenesis and angiogenesis, extracellular matrix elements, and coordinated suppression of oxidoreductase enzymes, all processes that would be directly or indirectly regulated by the activation of HIF1 $\alpha$ and/or HIF2 $\alpha$ (Dahia et al. 2005, Selak et al. 2005, Mole et al. 2009, Favier \& Gimenez-Roqueplo 2010, Semenza 2010, 2011, 2012, Keith et al. 2012). HIF1 $\alpha$ and HIF $2 \alpha$ regulate both shared and unique target genes and pathways. The common shared targets are vascular endothelial growth factor (VEGF), GLUT1, GLUT3, and hexokinase 2 (HK2). HIF1 $\alpha$ exclusively stimulates the expression of several glycolytic enzymes, whereas the embryonic transcription factors Oct4, cyclin D1, plateletderived growth factor, and erythropoietin are activated in a HIF2 $\alpha$-dependent manner (Fig. 2; Rankin et al. 2007, Patel \& Simon 2008, Furlow et al. 2009, Florczyk et al. 2011, Koh et al. 2011, Franke et al. 2013, Singh et al. 2013). The differential effects of these two transcription factors in numerous cellular systems are now well established and reviewed, including their link to the pathogenesis of PHEO and PGL (Holmquist-Mengelbier et al. 2006, Koh et al. 2011, Branco-Price et al. 2012, Chiavarina et al. 2012, Keith et al. 2012, Semenza 2012, Jochmanova et al. 2013). Despite the fact that Pollard et al. $(2005,2006)$ found relatively more common HIF2 $\alpha$ overexpression in VHL PHEOs and PGLs, whereas in $S D H x$-related tumors nuclear HIF1 $\alpha$ staining was more prominent, Gimenez-Roqueplo et al. $(2001,2002)$ described overexpression of HIF $2 \alpha$ and VEGF in patients with PHEOs and PGLs carrying $S D H B$ and $S D H D$ mutations compared with sporadic PHEOs and PGLs, and Favier et al. (2009) found overexpression of $H I F 2 \alpha$ mRNA in both VHL and SDH-related PHEO and PGL. Also, Eisenhofer et al. (2004) and Koh et al. (2011) support the leading role of HIF $2 \alpha$ in the tumor development and progression in cluster 1 tumors as well as their unique noradrenergic phenotype (Jochmanova et al. 2013). The important role of HIF $2 \alpha$ in various developmental issues is also supported by previous observations performed in fetal paraganglia and neuroblastoma (Tian et al. 1998, Favier et al. 1999, Nilsson et al. 2005, Jochmanova et al. 2013).

Similarly, the mechanism of PHD inhibition by succinate is likely to extend to other numbers of a large superfamily of $\alpha$-ketoglutarate-dependent dioxygenases. One of them is the factor inhibiting HIF, which normally hydroxylates HIF $1 \alpha$ on the asparagine 803 residue. This blocks its interaction with the coactivators histone acetyltransferase p300 (p300) and cAMP-response element-binding protein under normoxic conditions (Mahon et al. 2001, Lando et al. 2002) and thus inhibits the transactivation of HIF target genes (Khan et al. 2011, Cascon \& Tennant 2012). Also, SDHx mutations inhibit the activity of the jumonji-domain (JmjC) histone demethylases (Cervera et al. 2009, Xiao et al. 2012). These enzymes use $\alpha$-ketoglutarate to remove the methyl groups found on arginines and lysines of histones $\mathrm{H} 3$ and H4 (Agger et al. 2008). SDHx mutations decrease histone demethylase activity (specifically the JMJD3 demethylase) and lead to increased methylation of histone $\mathrm{H} 3$ (H3K27me3) (Cervera et al. 2009). Similarly, very recently Letouze et al. (2013) showed that increased tumor levels of succinate lead to DNA hypermethylation, a process causing global changes in gene expression as a critical tumorigenic mechanism. These modulations in the pseudohypoxic signature observed in $S D H x$-related tumors can distinguish the gene expression phenotypes observed in the two subgroups of tumors in cluster 1 .

Published by Bioscientifica Ltd 


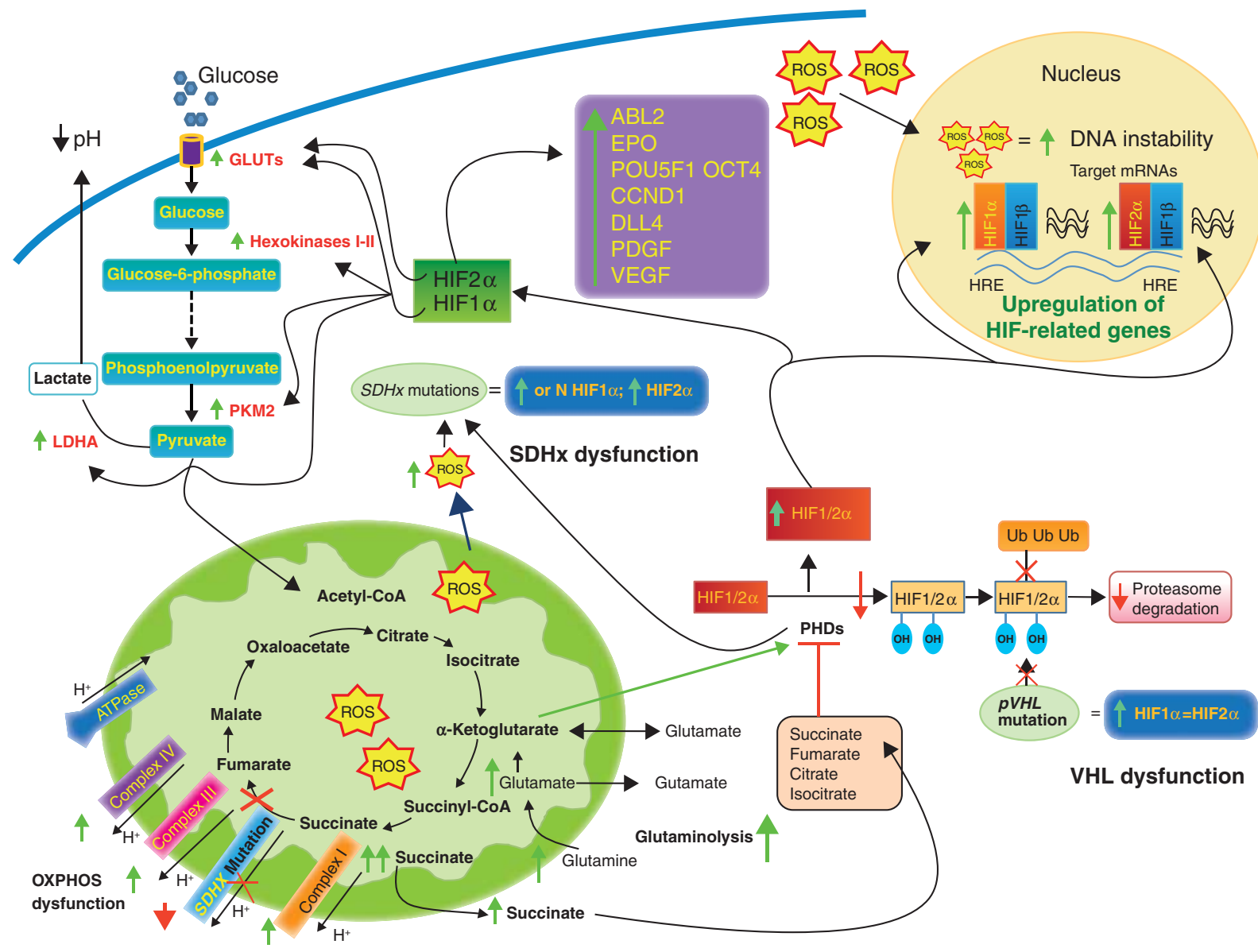

\section{Figure 2}

Different mechanisms have been proposed to explain the link between $S D H x$ mutations and tumorigenesis. First, the loss of function of SDH causes an accumulation of succinate and the overproduction of ROS. Second, inactivation or dysfunction of SDH inhibits the activity of HIF $\alpha$ PHDs. Inhibition of PHDs results in an insufficient hydroxylation of HIF1/2 $\alpha$. The unhydroxylated HIF $1 / 2 \alpha$ protein cannot be degraded by the proteasome, and HIF $1 / 2 \alpha$ is stabilized. This stabilization can be overcome by $\alpha$-ketoglutarate. VHL mutations result in similar inadequate HIF $1 / 2 \alpha$ proteasome degradation and HIF $1 / 2 \alpha$ stabilization. The stabilization of HIF1 $\alpha$ rather than HIF2 $\alpha$ increases glycolysis (due to overexpression of some glycolytic enzymes) and can regulate glutaminolysis. HIF2 $\alpha$ stabilization is involved in the direct or indirect activation of a number of genes that are known to be involved in the inhibition of apoptosis, tumorigenesis, and angiogenesis. The stabilization of HIF1/2 $\alpha$ leads to an upregulation of HIF-related genes due to binding to HREs and to an overexpression

\section{Reactive oxygen species}

A lack of SDH activity results in increases in steady-state levels of $\mathrm{O}_{2}^{-}$to $\mathrm{H}_{2} \mathrm{O}_{2}$ that could then form more powerful oxidants, such as hydroxyl radicals, through Haber-Weissdriven Fenton chemistry as well as organic hydroperoxides capable of causing chronic metabolic oxidative stress (Slane et al. 2006, Spitz 2011, Owens et al. 2012). Chronic ROS exposure can result in oxidative damage to mitochondrial and cellular proteins, lipids, and nucleic acids. of hypoxia-related genes. Increased ROS accumulation results in oxidative DNA damage and genomic instability and inhibits PHDs, similarly to the accumulation of succinate. Increasing activity of complex I, III, and IV may be a compensatory reaction to a lack of, or decreased, complex II activity in $S D H x$-related tumors. ABL2, ABL2 protein tyrosine-protein kinase; CCDN1, cyclin D1; DLL4, delta-like protein 4; EPO, erythropoietin; GLUTs, glucose transporters; HIF, hypoxia-inducible factor; HREs, hypoxia-responsive elements; LDH-A, lactate dehydrogenase A; OXPHOS, oxidative phosphorylation; PDGF, platelet-derived growth factor; PHDs, prolyl hydroxylases; PKM2, pyruvate kinase muscle isozyme 2; POU5F1 OCT4, POU domain, class 5, tarnscription factor 1 isoform; $\mathrm{pVHL}$, protein of the von Hippel-Lindau tumor suppressor gene; ROS, reactive oxygen species; SDH, succinate dehydrogenase; Ub, ubiquitin; VEGF, vascular endothelial growth factor.

These normoxic ROS accelerate the DNA-damaging processes as a 'mutator phenotype', causing genomic instability, as well as an increase in glucose consumption and sensitivity to glucose deprivation-induced toxicity and slower growth rates. ROS are also involved in Ras-RafMEK signaling. Ras-Raf-MEK signaling activation causes the mediation of protection against apoptotic cell death induced by increased oxidative stress (Jiang et al. 2005). The activity of the ROS-generating enzyme Nox1 is 
required for VEGF, a potent stimulator of tumor angiogenesis (Rustin et al. 2002, Dudkina et al. 2005, Slane et al. 2006, Pan et al. 2009). Fliedner et al. (2012) detected elevated superoxide dismutase 2 expression in $S D H B$ derived PHEOs/PGLs that is an indirect evidence for increased ROS production and may reflect elevated oxidative stress.

\section{Warburg effect}

A lack of SDH activity and consequent other changes lead to the Warburg effect in $S D H x$-related tumors. Because metabolic control over the glycolytic rate can be applied at many steps in the glycolytic pathway (Dang et al. 1997, Gatenby \& Gillies 2004), most studies in cancer support the hypothesis that control over glycolytic flux primarily resides at the transport and phosphorylation steps (upregulation of glucose transporters (notably GLUT1 and GLUT3) and HK2; Gatenby \& Gillies 2004, Mathupala et al. 2009, Choi et al. 2013). HIF $\alpha$ enhances the glycolytic pathway by increasing target gene expression from GLUT1, GLUT3, through HK2 and pyruvate kinase variant M2 (PKM2) to lactate dehydrogenase-A (LDH-A) and other glycolytic and anabolic enzymes and metabolites (Osthus et al. 2000, Soga 2013). Some expression studies have not found the overexpression of GLUT1 in SDHxrelated tumors (Favier et al. 2009, Lopez-Jimenez et al. 2010, Fliedner et al. 2012). Moreover, increased expression of GLUT3 and HK2 mRNAs observed in SDHx-related tumors (Favier et al. 2009, Fliedner et al. 2012) can explain the high sensitivity of $\left[{ }^{18} \mathrm{~F}\right]$-FDG PET for $S D H x$-related tumors, mainly observed in SDHB-related PHEOs/PGLs (Timmers et al. 2007, 2009b, 2012, Zelinka et al. 2008, Taieb et al. 2009). Fliedner et al. (2012) detected the M2 isoform of PKM2 mRNA, which appeared to be possibly elevated in $S D H B$-mutant tumors. PKM2 is generated by increased transcription and alternative splicing of the PKM2 gene through a HIF1 $\alpha$ and c-Myc-mediated process. $P K M 2$ catalyzes the final and also rate-limiting reaction in the glycolytic pathway and promotes tumorigenesis by regulating the Warburg effect. PKM2 also possesses a positive feedback regulation toward HIF1 $\alpha$. PKM2 interacts with HIF $1 \alpha$ in the nucleus and functions as a transcriptional coactivator to enhance the expression of HIF1 $\alpha$ target genes that promote the shift from OXPHOS to glycolytic metabolism (Luo \& Semenza 2011, 2012, Luo et al. 2011). Also, overexpression of LDH-A has been found in $S D H x$-related tumors (Favier et al. 2009, Fliedner et al. 2012). In proliferating cancer cells, the majority of the pyruvate generated from glucose $(>90 \%)$ is converted to lactate by LDH-A, where it is readily secreted into the extracellular environment. By converting pyruvate to lactate, LDH-A recovers the $\mathrm{NAD}^{+}$needed to maintain glycolysis and ATP production. This step is critical for the maintenance of tumor proliferation in vivo (Fantin et al. 2006, Jones \& Thompson 2009). LDH-A may be upregulated by a high glycolytic flux through the carbohydrateresponse elements (ChoREs) by binding HIF or myc products (Semenza 2002a,b, Walenta \& Mueller-Klieser 2004). Moreover, both LDH-A and mitochondria activity are mutually regulated at the level of metabolites. They depend on the availability of pyruvate and on the $\mathrm{NADH}: \mathrm{NAD}^{+}$ratio. The generation of lactate and the export of intracellular acid lead to an acidic tumor microenvironment, which is correlated with a poor prognosis and may facilitate tumor invasion and metastasis leading to the stimulation of cell migration and angiogenesis (Chiche et al. 2010, Vegran et al. 2011). Thus, activation of $\mathrm{HIF} \alpha, \mathrm{c}-\mathrm{myc}$, and other proteins stimulates many processes that result in the Warburg effect in these tumors (Vogelstein \& Kinzler 2004, Deberardinis et al. 2008, Yuneva 2008, Jones \& Thompson 2009, Gogvadze et al. 2010, Levine \& Puzio-Kuter 2010, Cairns et al. 2011, Koppenol et al. 2011).

\section{Glutamine metabolism}

Tannahill et al. (2013) showed a dysfunctional TCA cycle pointed toward an alternative source of succinate. The microarray study showed a significantly higher concentration of glutamine transporter SLC3A2 mRNA. Thus, substantial increases in succinate accumulation have been demonstrated through processes involving increased import and metabolism of glutamine (Tannahill et al. 2013). Therefore, we suggest that glutamine metabolism can be involved in $S D H x$-related tumors. Succinate can be derived from glutamine through anaplerosis by $\alpha$-ketoglutarate. Recently, Imperiale et al. (2013) found significantly lower values of glutamate in $S D H x$-related tumors compared with other subtypes. These catabolic pathways are reversible and involve the removal of nitrogen as part of the mechanism that regulates nitrogen homeostasis; the carbon skeleton from glutaminolysis may eventually enter anabolic or anaplerotic processes (including the formation of nucleotides, lipids, and proteins; Yuneva 2008, Dang 2010, Eng \& Abraham 2010).

Meng et al. (2010) observed that nitrogen source restriction repressed carbon metabolic pathways, including glucose utilization. Therefore, the interconversion between glutamine and $\alpha$-ketoglutarate serves as the

Published by Bioscientifica Ltd 
bridge connecting nitrogen and carbon metabolism. Thus, glutaminolysis and the Warburg effect become two integral parts of the cellular machinery to balance the carbon and nitrogen metabolism. Glutaminolysis also supports the production of molecules, such as GSH and $\mathrm{NADPH}$, which protect cells from oxidative stress.

\section{OXPHOS proteins}

OXPHOS proteins include the electron transport chain components, ATP synthase, and the adenine nucleotide translocator. Information about other OXPHOS proteins besides complex II in $S D H x$-related tumors is limited. Favier et al. (2009) suggested a lower expression of OXPHOS protein complexes I-IV in SDHx- and VHLrelated tumors than in PHEOs/PGLs harboring NF1 and RET mutations, but complex $\mathrm{V}$ expression was relatively similar in all patients. Also, the activity of complexes II, III, or IV was found to be decreased in $S D H X$ - and VHL-related PHEOs/PGLs, but the differences were smaller for complexes III and IV. In contrast, other groups showed that the activity of SDH or respiratory chain enzyme complex II is low in $S D H x$-related tumors and associated with increased activities of respiratory chain complexes I, III, and IV and citrate synthase. All these factors suggest a compensatory response to the lack of SDH activity (Fliedner et al. 2012, Rao et al. 2013). However, as shown by Rao et al. (2013), the apparently increased activity of complex I, III, IV, and citrate synthase in the $S D H x$-related tumors does not lead to a full restoration of ATP/AD$\mathrm{P} / \mathrm{AMP}$, because the concentration of ATP/ADP/AMP was consistently very low in all $S D H x$-related tumors. Rao et al. found positive relationships between mitochondrial complex II function, tumor ATP/ADP/AMP content, and tumor catecholamine contents, and suggested the possibility that differences in energy metabolism might also contribute to the lower tumor tissue catecholamine contents in cluster 1 than in cluster 2 tumors. Thus, increased activity of complex I, III, and IV may be a compensatory reaction to a lack of or decreased complex II activity in these tumors.

Thus, the generation of ROS as well as pseudohypoxia and succinate accumulation results in significant changes in key pathways: HIF, glycolysis, angiogenesis, genomic instability, increased cell cycle, and increased mutability.

In summary, increased ROS production has been suggested to contribute to tumorigenesis in $S D H B$-related tumors (Guzy et al. 2008, Goffrini et al. 2009, Huang \& Lemire 2009). SDHx mutation-induced increases in ROS have recently been shown to cause genomic instability that may contribute to tumorigenesis (Slane et al. 2006, Owens et al. 2012). Second, accumulation of succinate leads to widespread changes, from stabilization of HIF $\alpha$ through inhibition of PHD to DNA hypermethylation, a process causing global changes in gene expression. This accumulation of succinate accompanies low fumarate in malignant $S D H B$ tumors. This high succinate:fumarate ratio can be used as a predictor of malignancy in the future. Third, the specific catecholamine phenotype in $S D H x$-related tumors may be due to downregulation of HIF $1 \alpha$ and upregulation of HIF $2 \alpha$. Fourth, not only glycolysis but also glutaminolysis may be involved in $S D H x$-related tumors.

\section{Future treatment options to attack metabolic alterations in SDHX-related tumors}

Understanding specific metabolic alterations characteristic and unique to $S D H x$-related PHEOs/PGLs and increasing availability and implementation of molecular profiling and metabolomics in clinical medicine opens new promising options for the use of multiple and personalized metabolic-specific molecular-targeted therapies in the near future, as originally suggested by Eng et al. (2003). Several key events involved in the pathogenesis of $S D H x$-related PHEOs/PGLs have been described, such as i) an increase in ROS production resulting in oxidative stress and stabilization of HIF $1 / 2 \alpha$ and ii) accumulation of succinate which inhibits 2OG-dependent dioxygenases and causes hypermethylated and pseudohypoxic phenotypes. Identification of subgroups of specific molecularmetabolic phenotypes may be especially useful in personalized medicine. Furthermore, targeted therapies hold promise for the treatment of metastatic $S D H x$-related tumors. Thus, although outlined below separately, these approaches are viewed as tightly interconnected and should be combined when appropriate treatments or knowledge are available.

\section{Restoration of SDH activity}

An increase in the expression and stabilization of SDH proteins is crucial to prevent various metabolic dysregulations resulting from the absence of SDHB protein and therefore dysfunctional mitochondrial complex II in $S D H x$-related tumors. An increase in the expression and stabilization of SDH proteins is crucial to prevent various metabolic dysregulations resulting from the absence of SDHB protein and therefore dysfunctional mitochondrial

Published by Bioscientifica Ltd 
complex II in SDHx-related tumors. Recently, Yang and colleagues demonstrated that the loss of SDHB function was due to a reduced half-life of mutant protein by rapid proteasome degradation. The authors found that histone deacetylase inhibitors (HDACi) inhibited proteasome degradation of SDHB-mutated protein resulting in its increased stabilization and activity (Yang et al. 2012). However, this approach, although of interest in the near future, cannot be applied to patients with nonsense $S D H x$ mutations or $S D H x$ gene deletions, because no protein is generated and the second allele is missing by the mechanism of loss of heterozygosity. Furthermore, it is expected that this approach will only partially increase the availability of mutated (and still dysfunctional) protein that will only improve mitochondrial function to a certain degree leading to persistent metabolic dysregulations (although to a lesser degree). Therefore, this therapy most likely will need to be combined with other therapeutic approaches.

\section{Restoration of PHD activity}

As described in our study, both succinate and ROS contribute to the inactivation of PHD and subsequent stabilization of the HIF $1 / 2 \alpha$ signaling pathway. PHD action normally requires oxygen and $\alpha$-ketoglutarate as co-substrates. PHD inactivation by succinate is competitive with $\alpha$-ketoglutarate. Therefore, increasing the $\alpha$-ketoglutarate:succinate ratio levels by treatment with $\alpha$-ketoglutarate derivatives could critically affect PHD activity and decrease the stabilization of HIF $1 / 2 \alpha$ (MacKenzie et al. 2007, Tennant et al. 2009, Jokilehto \& Jaakkola 2010). Furthermore, esterified $\alpha$-ketoglutarate induces apoptosis and inhibits tumor growth. These effects are independent of HIF $\alpha$ but dependent on the presence of PHD3 (Tennant \& Gottlieb 2010).

Direct activation of PHD by the activator KRH102053 increases HIF $1 / 2 \alpha$ hydroxylation and promotes its degradation (Choi et al. 2008, Nepal et al. 2011). Targeting HIF $1 / 2 \alpha$ with their specific inhibitors (e.g. currently by either the direct inhibitor PX-478 or the indirect inhibitor PX-12; both targeted to HIF1 $\alpha$ ) has shown antitumoral activity in human tumor xenografts in mice and also seems to be promising for malignant PHEO/PGL (Welsh et al. 2003, 2004, Semenza 2007). However, currently there are no HIF $2 \alpha$ inhibitors that would be preferable in the treatment of $S D H x$-related PHEO/PGL. Nevertheless, it is expected that these compounds will be introduced in the near future (Rogers et al. 2013).

\section{Prevent ROS damage}

A rationale for using antioxidants in HIF $1 / 2 \alpha$-driven tumors was recently provided by Gao et al. (2007), who examined the antitumorigenic effect of the antioxidant NAC. They reported that NAC treatment resulted in reduced HIF1 $\alpha$ expression and inhibition of in vivo tumor formation in a HIF-driven model of tumorigenesis. Ni \& Eng (2012) concluded that the lipid-soluble antioxidant $\alpha$-tocopherol can selectively protect $S D H x^{v a r+}$ cells from oxidative damage and apoptosis resistance and rebalance the redox metabolites, NAD/NADH, which is a promising opportunity to prevent the development of tumors in patients with $S D H x$ mutations. This concept is very unique, introducing prevention for the first time in the treatment of $S D H x$ carriers. Thus, $\alpha$-tocopherol, ascorbic acid, and HDACi could be administered over a long period and could serve as a novel therapeutic paradigm for preventing the development of $S D H x$-related PHEOs/PGLs (Ni \& Eng 2012, Yang et al. 2012).

\section{Heat shock protein 90 inhibitors}

Malignant $S D H x$-related PHEO/PGL overexpresses heat shock protein 90 (HSP90), a molecular chaperone that assists in binding to HIF $1 / 2 \alpha$ and promotes its stability by preventing ubiquitination and proteasomal degradation of HIF1/2 $\alpha$ (Liu et al. 2007, Mahalingam et al. 2009, Semenza 2010). Thus, inhibitors of HSP90, such as geldanamycin, and analogs, such as 17-allylamino geldanamycin (17-AAG; tanespimycin), 17-dimethylaminoethylamino17-demethoxygeldanamycin (alespimicin), or other new analogs, are promising therapeutic agents (Isaacs et al. 2002, Northcott et al. 2012). Giubelino et al. (2013) demonstrated the potent inhibition of proliferation and migration of PHEO cell lines and induced degradation of key Hsp90 clients by 17-AAG and ganetespib. They also showed the efficacy of 17-AAG and ganetespib in reducing metastatic burden and increasing survival in metastatic model of PHEO (Giubellino et al. 2013).

\section{Glycolysis inhibition}

In addition, when the TCA cycle is genetically compromised, as is the case in $S D H x$-related PHEO/PGL, glycolytic addiction of the tumor cells is ensured. These tumors are 'glucose addicts' as revealed by their almost $100 \%$ of positivity on $\left[{ }^{18} \mathrm{~F}\right]$-FDG PET. This may prove to be an Achilles' heel of these tumors. Thus, strategies disrupting glycolytic mechanisms can be used in the future.

Published by Bioscientifica Ltd. 
A small-molecule inhibitor of GLUT1, such as WZB117 or STF-31, downregulates glycolysis and inhibits cancer cell growth in vitro and in vivo (Chan et al. 2011, Liu et al. 2012). In addition, dichloroacetate (DCA) and 3-bromopyruvate reverse cancer-specific aerobic glycolysis (Michelakis et al. 2008, Cardaci et al. 2012, El Sayed et al. 2012, Kluza et al. 2012, Kumar et al. 2012, Matsushita et al. 2012, Sutendra \& Michelakis 2013, Sutendra et al. 2013). DCA downregulates pyruvate dehydrogenase kinase, which, under normal conditions, upregulates the glycolysis enzyme pyruvate dehydrogenase (Michelakis et al. 2008, Kluza et al. 2012, Kumar et al. 2012, Sutendra \& Michelakis 2013, Sutendra et al. 2013), shifting metabolism from glycolysis to glucose oxidation and selectively inducing apoptosis in cancer cells (Xie et al. 2011). Furthermore, inhibitors of HK2 (Pedersen 2012, Yu et al. 2012) may also represent a novel therapeutic approach to malignant $S D H x$-related PHEO/PGL.

\section{Disruption of $\mathrm{pH}$ regulators}

In addition, activation of the HIF $1 \alpha$ pathway enhances glycolytic metabolism and generates increased amounts of lactic and carbonic acids. This poses considerable cellular stress and requires a continuous regulation by several $\mathrm{pH}$-regulating systems. It has been shown that disruption of these proteins may provide an effective avenue for future targeted therapies in different cancer models (Parks et al. 2013). However, several studies have shown a predominant expression of HIF $2 \alpha$ over HIF $1 \alpha$ in $S D H$ related tumors (Eisenhofer et al. 2004, Favier et al. 2009, Jochmanova et al. 2013), suggesting a leading role for HIF $\alpha$ in $S D H x$-related tumorigenesis. Thus, the identification of subgroups of patients with preferential or combined activation of HIF $1 \alpha$ or HIF $1 / 2 \alpha$, respectively, would help in the development of 'personalized' approaches in this type of therapy. In these patients, disrupting pH-regulating capacities and the export of lactic acid from tumor cells (by disrupting monocarboxylate transporters (MCTs)) could reduce glycolysis and growth rates. Additional strategies could be developed by disrupting glycolytic mechanisms.

\section{Disruption of alternative signaling pathways}

Additional treatment strategies could target abnormally functioning pathways, possibly in conjunction with targeting metabolic pathways. For example, the pseudohypoxic response and abnormal energy status of tumor cells activate kinase signaling pathways such as
PI3kinase/AKT, RAS/RAF/ERK, and mTOR1/p70s6K, which leads to abnormal cell growth and a lack of apoptotic capacity (Abraham \& Eng 2010, Choo et al. 2010, Nolting \& Grossman 2012). Favier et al. (2012) showed that the mTOR pathway was potentially activated in half of PHEO/PGLs. Nolting et al. (2012) showed that combination treatment with dual NVP-BEZ235 (a PI3K/ mTORC1 inhibitor) and lovastatin (an inhibitor of ERK signaling) had a significant additive effect in mice PHEO MPC and MTT cells and resulted in the inhibition of both AKT and mTORC1/p70S6K signaling without ERK upregulation. However, recently, Ghayee et al. (2013) suggested that the use of mTOR inhibitors alone for metastatic SDHB PHEOs/PGLs may not achieve good therapeutic efficacy in these patients.

\section{Summary}

Recent advances and insights into $S D H x$-related PHEOs/PGLs as tumors with significant changes in their metabolism may lead to major advances in the treatment of these tumors.

\section{Declaration of interest}

The authors declare that there is no conflict of interest that could be perceived as prejudicing the impartiality of the review.

\section{Funding}

This work was supported by the Intramural Research Program of the Eunice Kennedy Shriver National Institute of Child Health and Human Development and the National Institute of Neurological Disorders and Stroke at the National Institutes of Health, and by MH CZ - DRO, University Hospital Motol, Prague, Czech Republic 00064203.

Author contribution statement

A Vicha, D Taieb, and K Pacak contributed to the manuscript conception and design, data collection and interpretation, writing, editing, and final proof. K Pacak provided administrative support.

\section{Acknowledgements}

This work was supported by the Intramural Research Program of the Eunice Kennedy Shriver National Institute of Child Health and Human Development at the National Institutes of Health. The authors thank Victoria Martucci and Ankita Reddy for their technical assistance.

\section{References}

Abraham RT \& Eng CH 2010 A metabolic (re-)balancing act. Molecular Cell 38 481-482. (doi:10.1016/j.molcel.2010.05.008)

Published by Bioscientifica Ltd. 
Agger K, Christensen J, Cloos PA \& Helin K 2008 The emerging functions of histone demethylases. Current Opinion in Genetics \& Development 18 159-168. (doi:10.1016/j.gde.2007.12.003)

Alston CL, Davison JE, Meloni F, van der Westhuizen FH, He L, Hornig-Do HT, Peet AC, Gissen P, Goffrini P, Ferrero I et al. 2012 Recessive germline SDHA and SDHB mutations causing leukodystrophy and isolated mitochondrial complex II deficiency. Journal of Medical Genetics 49 569-577. (doi:10.1136/jmedgenet-2012-101146)

Astuti D, Latif F, Dallol A, Dahia PL, Douglas F, George E, Skoldberg F, Husebye ES, Eng C \& Maher ER 2001 Gene mutations in the succinate dehydrogenase subunit SDHB cause susceptibility to familial pheochromocytoma and to familial paraganglioma. American Journal of Human Genetics 69 49-54. (doi:10.1086/321282)

Astuti D, Hart-Holden N, Latif F, Lalloo F, Black GC, Lim C, Moran A, Grossman AB, Hodgson SV, Freemont A et al. 2003 Genetic analysis of mitochondrial complex II subunits SDHD, SDHB and SDHC in paraganglioma and phaeochromocytoma susceptibility. Clinical Endocrinology 59 728-733. (doi:10.1046/j.1365-2265.2003.01914.x)

Astuti D, Morris M, Krona C, Abel F, Gentle D, Martinsson T, Kogner P, Neumann HP, Voutilainen R, Eng C et al. 2004 Investigation of the role of SDHB inactivation in sporadic phaeochromocytoma and neuroblastoma. British Journal of Cancer 91 1835-1841. (doi:10.1038/ sj.bjc.6602202)

Bardella C, Pollard PJ \& Tomlinson I 2011 SDH mutations in cancer. Biochimica et Biophysica Acta 1807 1432-1443. (doi:10.1016/j.bbabio. 2011.07.003)

Bayley JP, Devilee P \& Taschner PE 2005 The SDH mutation database: an online resource for succinate dehydrogenase sequence variants involved in pheochromocytoma, paraganglioma and mitochondrial complex II deficiency. BMC Medical Genetics 6 39. (doi:10.1186/ 1471-2350-6-39)

Bayley JP, van Minderhout I, Weiss MM, Jansen JC, Oomen PH, Menko FH, Pasini B, Ferrando B, Wong N, Alpert LC et al. 2006 Mutation analysis of SDHB and SDHC: novel germline mutations in sporadic head and neck paraganglioma and familial paraganglioma and/or pheochromocytoma. BMC Medical Genetics 7 1. (doi:10.1186/1471-2350-7-1)

Baysal BE 2003 On the association of succinate dehydrogenase mutations with hereditary paraganglioma. Trends in Endocrinology and Metabolism 14 453-459. (doi:10.1016/j.tem.2003.08.004)

Baysal BE 2004 Genomic imprinting and environment in hereditary paraganglioma. American Journal of Medical Genetics. Part C, Seminars in Medical Genetics 129C 85-90. (doi:10.1002/ajmg.c.30018)

Baysal BE 2008 Clinical and molecular progress in hereditary paraganglioma. Journal of Medical Genetics 45 689-694. (doi:10.1136/jmg.2008. 058560)

Baysal BE, Ferrell RE, Willett-Brozick JE, Lawrence EC, Myssiorek D, Bosch A, van der Mey A, Taschner PE, Rubinstein WS, Myers EN et al. 2000 Mutations in SDHD, a mitochondrial complex II gene, in hereditary paraganglioma. Science 287 848-851. (doi:10.1126/science. 287.5454.848)

Benn DE, Gimenez-Roqueplo AP, Reilly JR, Bertherat J, Burgess J, Byth K, Croxson M, Dahia PL, Elston M, Gimm O et al. 2006 Clinical presentation and penetrance of pheochromocytoma/paraganglioma syndromes. Journal of Clinical Endocrinology and Metabolism 91 827-836. (doi:10.1210/jc.2005-1862)

Bensinger SJ \& Christofk HR 2012 New aspects of the Warburg effect in cancer cell biology. Seminars in Cell \& Developmental Biology 23 352-361. (doi:10.1016/j.semcdb.2012.02.003)

Birch-Machin MA, Taylor RW, Cochran B, Ackrell BA \& Turnbull DM 2000 Late-onset optic atrophy, ataxia, and myopathy associated with a mutation of a complex II gene. Annals of Neurology 48 330-335. (doi:10.1002/1531-8249(200009)48:3<330::AID-ANA7>3.0.CO;2-A)

Branco-Price C, Zhang N, Schnelle M, Evans C, Katschinski DM, Liao D, Ellies L \& Johnson RS 2012 Endothelial cell HIF- $1 \alpha$ and HIF- $2 \alpha$ differentially regulate metastatic success. Cancer Cell 21 52-65. (doi:10.1016/j.ccr.2011.11.017)
Burnichon N, Rohmer V, Amar L, Herman P, Leboulleux S, Darrouzet V, Niccoli P, Gaillard D, Chabrier G, Chabolle F et al. 2009 The succinate dehydrogenase genetic testing in a large prospective series of patients with paragangliomas. Journal of Clinical Endocrinology and Metabolism 94 2817-2827. (doi:10.1210/jc.2008-2504)

Burnichon N, Briere JJ, Libe R, Vescovo L, Riviere J, Tissier F, Jouanno E, Jeunemaitre X, Benit P, Tzagoloff A et al. 2010 SDHA is a tumor suppressor gene causing paraganglioma. Human Molecular Genetics 19 3011-3020. (doi:10.1093/hmg/ddq206)

Burnichon N, Vescovo L, Amar L, Libe R, de Reynies A, Venisse A, Jouanno E, Laurendeau I, Parfait B, Bertherat J et al. 2011 Integrative genomic analysis reveals somatic mutations in pheochromocytoma and paraganglioma. Human Molecular Genetics 20 3974-3985. (doi:10.1093/hmg/ ddr324)

Burnichon N, Buffet A, Parfait B, Letouze E, Laurendeau I, Loriot C, Pasmant E, Abermil N, Valeyrie-Allanore L, Bertherat J et al. $2012 a$ Somatic NF1 inactivation is a frequent event in sporadic pheochromocytoma. Human Molecular Genetics 21 5397-5405. (doi:10.1093/ hmg/dds374)

Burnichon N, Cascon A, Schiavi F, Morales NP, Comino-Mendez I, Abermil N, Inglada-Perez L, de Cubas AA, Amar L, Barontini $\mathrm{M}$ et al. $2012 b$ MAX mutations cause hereditary and sporadic pheochromocytoma and paraganglioma. Clinical Cancer Research 18 2828-2837. (doi:10.1158/1078-0432.CCR-12-0160)

Cairns RA, Harris IS \& Mak TW 2011 Regulation of cancer cell metabolism. Nature Reviews. Cancer 11 85-95. (doi:10.1038/nrc2981)

Cardaci S, Desideri E \& Ciriolo MR 2012 Targeting aerobic glycolysis: 3-bromopyruvate as a promising anticancer drug. Journal of Bioenergetics and Biomembranes 44 17-29. (doi:10.1007/s10863-012-9422-7)

Cascon A \& Tennant DA 2012 From transcriptional profiling to tumor biology in pheochromocytoma and paraganglioma. Endocrine Pathology 23 15-20. (doi:10.1007/s12022-012-9195-x)

Cascon A, Landa I, Lopez-Jimenez E, Diez-Hernandez A, Buchta M, Montero-Conde C, Leskela S, Leandro-Garcia LJ, Leton R, RodriguezAntona C et al. 2008 Molecular characterisation of a common SDHB deletion in paraganglioma patients. Journal of Medical Genetics $\mathbf{4 5}$ 233-238. (doi:10.1136/jmg.2007.054965)

Castro-Vega LJ, Buffet A, de Cubas AA, Cascon A, Menara M, Khalifa E, Amar L, Azriel S, Bourdeau I, Chabre O et al. 2014 Germline mutations in FH confer predisposition to malignant pheochromocytomas and paragangliomas. Human Molecular Genetics 23 2440-2446. (doi:10.1093/hmg/ddt639)

Cervera AM, Bayley JP, Devilee P \& McCreath KJ 2009 Inhibition of succinate dehydrogenase dysregulates histone modification in mammalian cells. Molecular Cancer 8 89. (doi:10.1186/1476-4598-8-89)

Chan DA, Sutphin PD, Nguyen P, Turcotte S, Lai EW, Banh A, Reynolds GE, Chi JT, Wu J, Solow-Cordero DE et al. 2011 Targeting GLUT1 and the Warburg effect in renal cell carcinoma by chemical synthetic lethality. Science Translational Medicine 3 94ra70.

Chiavarina B, Martinez-Outschoorn UE, Whitaker-Menezes D, Howell A Tanowitz HB, Pestell RG, Sotgia F \& Lisanti MP 2012 Metabolic reprogramming and two-compartment tumor metabolism: opposing role(s) of HIF1 $\alpha$ and HIF $2 \alpha$ in tumor-associated fibroblasts and human breast cancer cells. Cell Cycle 11 3280-3289. (doi:10.4161/cc.21643)

Chiche J, Brahimi-Horn MC \& Pouyssegur J 2010 Tumour hypoxia induces a metabolic shift causing acidosis: a common feature in cancer. Journal of Cellular and Molecular Medicine 14 771-794. (doi:10.1111/ j.1582-4934.2009.00994.x)

Choi HJ, Song BJ, Gong YD, Gwak WJ \& Soh Y 2008 Rapid degradation of hypoxia-inducible factor- $1 \alpha$ by KRH102053, a new activator of prolyl hydroxylase 2. British Journal of Pharmacology 154 114-125. (doi:10.1038/bjp.2008.70)

Choi J, Jung WH \& Koo JS 2013 Metabolism-related proteins are differentially expressed according to the molecular subtype of invasive breast cancer defined by surrogate immunohistochemistry. Pathobiology 80 41-52. (doi:10.1159/000339513) 
Choo AY, Kim SG, Vander Heiden MG, Mahoney SJ, Vu H, Yoon SO, Cantley LC \& Blenis J 2010 Glucose addiction of TSC null cells is caused by failed mTORC1-dependent balancing of metabolic demand with supply. Molecular Cell 38 487-499. (doi:10.1016/j.molcel.2010.05.007)

Comino-Mendez I, Gracia-Aznarez FJ, Schiavi F, Landa I, Leandro-Garcia LJ, Leton R, Honrado E, Ramos-Medina R, Caronia D, Pita G et al. 2011 Exome sequencing identifies MAX mutations as a cause of hereditary pheochromocytoma. Nature Genetics 43 663-667. (doi:10.1038/ng.861)

Crona J, Delgado Verdugo A, Maharjan R, Stalberg P, Granberg D, Hellman P \& Bjorklund P 2013 Somatic mutations in H-RAS in sporadic pheochromocytoma and paraganglioma identified by exome sequencing. Journal of Clinical Endocrinology and Metabolism 98 E1266-E1271. (doi:10.1210/jc.2012-4257)

Dahia PL 2013 The genetic landscape of pheochromocytomas and paragangliomas: somatic mutations take center stage. Journal of Clinical Endocrinology and Metabolism 98 2679-2681. (doi:10.1210/ jc.2013-2191)

Dahia PL, Ross KN, Wright ME, Hayashida CY, Santagata S, Barontini M, Kung AL, Sanso G, Powers JF, Tischler AS et al. 2005 A HIF1 $\alpha$ regulatory loop links hypoxia and mitochondrial signals in pheochromocytomas. PLoS Genetics 1 72-80. (doi:10.1371/journal.pgen.0010008)

Dang CV 2010 Glutaminolysis: supplying carbon or nitrogen or both for cancer cells? Cell Cycle 9 3884-3886. (doi:10.4161/cc.9.19.13302)

Dang CV, Lewis BC, Dolde C, Dang G \& Shim H 1997 Oncogenes in tumor metabolism, tumorigenesis, and apoptosis. Journal of Bioenergetics and Biomembranes 29 345-354. (doi:10.1023/A:1022446730452)

Dang L, White DW, Gross S, Bennett BD, Bittinger MA, Driggers EM, Fantin VR, Jang HG, Jin S, Keenan MC et al. 2009 Cancer-associated IDH1 mutations produce 2-hydroxyglutarate. Nature 462 739-744. (doi:10.1038/nature08617)

Dann CE III \& Bruick RK 2005 Dioxygenases as $\mathrm{O}_{2}$-dependent regulators of the hypoxic response pathway. Biochemical and Biophysical Research Communications 338 639-647. (doi:10.1016/j.bbrc.2005.08.140)

Deberardinis RJ, Sayed N, Ditsworth D \& Thompson CB 2008 Brick by brick: metabolism and tumor cell growth. Current Opinion in Genetics \& Development 18 54-61. (doi:10.1016/j.gde.2008.02.003)

Dudkina NV, Eubel H, Keegstra W, Boekema EJ \& Braun HP 2005 Structure of a mitochondrial supercomplex formed by respiratory-chain complexes I and III. PNAS 102 3225-3229. (doi:10.1073/pnas. 0408870102)

Eakin RT, Morgan LO, Gregg CT \& Matwiyoff NA 1972 Carbon-13 nuclear magnetic resonance spectroscopy of living cells and their metabolism of a specifically labeled ${ }^{13} \mathrm{C}$ substrate. FEBS Letters 28 259-264. (doi:10.1016/0014-5793(72)80726-9)

Eisenhofer G, Huynh TT, Pacak K, Brouwers FM, Walther MM, Linehan WM, Munson PJ, Mannelli M, Goldstein DS \& Elkahloun AG 2004 Distinct gene expression profiles in norepinephrine- and epinephrine-producing hereditary and sporadic pheochromocytomas: activation of hypoxiadriven angiogenic pathways in von Hippel-Lindau syndrome. Endocrine-Related Cancer 11 897-911. (doi:10.1677/erc.1.00838)

Eisenhofer G, Pacak K, Huynh TT, Qin N, Bratslavsky G, Linehan WM, Mannelli M, Friberg P, Grebe SK, Timmers HJ et al. 2011 a Catecholamine metabolomic and secretory phenotypes in phaeochromocytoma. Endocrine-Related Cancer 18 97-111. (doi:10.1677/ERC-10-0211)

Eisenhofer G, Lenders JW, Timmers H, Mannelli M, Grebe SK, Hofbauer LC, Bornstein SR, Tiebel O, Adams K, Bratslavsky G et al. $2011 b$ Measurements of plasma methoxytyramine, normetanephrine, and metanephrine as discriminators of different hereditary forms of pheochromocytoma. Clinical Chemistry 57 411-420. (doi:10.1373/ clinchem.2010.153320)

Eisenhofer G, Lenders JW, Siegert G, Bornstein SR, Friberg P, Milosevic D, Mannelli M, Linehan WM, Adams K, Timmers HJ et al. 2012 Plasma methoxytyramine: a novel biomarker of metastatic pheochromocytoma and paraganglioma in relation to established risk factors of tumour size, location and SDHB mutation status. European Journal of Cancer 48 1739-1749. (doi:10.1016/j.ejca.2011.07.016)
El Sayed SM, El-Magd RM, Shishido Y, Chung SP, Diem TH, Sakai T, Watanabe H, Kagami S \& Fukui K 2012 3-Bromopyruvate antagonizes effects of lactate and pyruvate, synergizes with citrate and exerts novel anti-glioma effects. Journal of Bioenergetics and Biomembranes 44 61-79. (doi:10.1007/s10863-012-9409-4)

Eltzschig HK, Eckle T \& Grenz A 2009 PHD2 mutation and congenital erythrocytosis with paraganglioma. New England Journal of Medicine 360 1361-1362 (author reply 1362). (doi:10.1056/NEJMc090088)

Eng CH \& Abraham RT 2010 Glutaminolysis yields a metabolic by-product that stimulates autophagy. Autophagy 6 968-970. (doi:10.4161/ auto.6.7.13082)

Eng C, Kiuru M, Fernandez MJ \& Aaltonen LA 2003 A role for mitochondrial enzymes in inherited neoplasia and beyond. Nature Reviews. Cancer 3 193-202. (doi:10.1038/nrc1013)

Erlic Z, Rybicki L, Peczkowska M, Golcher H, Kann PH, Brauckhoff M, Mussig K, Muresan M, Schaffler A, Reisch N et al. 2009 Clinical predictors and algorithm for the genetic diagnosis of pheochromocytoma patients. Clinical Cancer Research 15 6378-6385. (doi:10.1158/ 1078-0432.CCR-09-1237)

Fantin VR, St-Pierre J \& Leder P 2006 Attenuation of LDH-A expression uncovers a link between glycolysis, mitochondrial physiology, and tumor maintenance. Cancer Cell 9 425-434. (doi:10.1016/j.ccr. 2006.04.023)

Favier J \& Gimenez-Roqueplo AP 2010 Pheochromocytomas: the (pseudo)hypoxia hypothesis. Best Practice \& Research. Clinical Endocrinology \& Metabolism 24 957-968. (doi:10.1016/j.beem.2010.10.004)

Favier J, Kempf H, Corvol P \& Gasc JM 1999 Cloning and expression pattern of EPAS1 in the chicken embryo. Colocalization with tyrosine hydroxylase. FEBS Letters 462 19-24. (doi:10.1016/S0014-5793(99) 01476-3)

Favier J, Briere JJ, Burnichon N, Riviere J, Vescovo L, Benit P, Giscos-Douriez I, De Reynies A, Bertherat J, Badoual C et al. 2009 The Warburg effect is genetically determined in inherited pheochromocytomas. PLOS ONE 4 e7094. (doi:10.1371/journal.pone.0007094)

Favier J, Igaz P, Burnichon N, Amar L, Libe R, Badoual C, Tissier F, Bertherat J, Plouin PF, Jeunemaitre X et al. 2012 Rationale for anti-angiogenic therapy in pheochromocytoma and paraganglioma. Endocrine Pathology 23 34-42. (doi:10.1007/s12022-011-9189-0)

Fliedner SMJ, Kaludercic N, Jiang X, Hansikova H, Hajkova Z, Sladkova J, Limpuangthip A, Backlund PS, Wesley R, Martiniova L et al. 2012 Warburg effect's manifestation in aggressive pheochromocytomas and paragangliomas: insights from a mouse cell model applied to human tumor tissue. PLoS ONE 7 e40949. (doi:10.1371/journal.pone.0040949)

Florczyk U, Czauderna S, Stachurska A, Tertil M, Nowak W, Kozakowska M, Poellinger L, Jozkowicz A, Loboda A \& Dulak J 2011 Opposite effects of HIF- $1 \alpha$ and HIF- $2 \alpha$ on the regulation of IL- 8 expression in endothelial cells. Free Radical Biology \& Medicine 51 1882-1892. (doi:10.1016/ j.freeradbiomed.2011.08.023)

Franke K, Gassmann M \& Wielockx B 2013 Erythrocytosis: the HIF pathway in control. Blood 122 1122-1128. (doi:10.1182/blood-2013-01-478065)

Furlow PW, Percy MJ, Sutherland S, Bierl C, McMullin MF, Master SR, Lappin TR \& Lee FS 2009 Erythrocytosis-associated HIF- $2 \alpha$ mutations demonstrate a critical role for residues C-terminal to the hydroxylacceptor proline. Journal of Biological Chemistry 284 9050-9058. (doi:10.1074/jbc.M808737200)

Gaal J, Burnichon N, Korpershoek E, Roncelin I, Bertherat J, Plouin PF, de Krijger RR, Gimenez-Roqueplo AP \& Dinjens WN 2010 Isocitrate dehydrogenase mutations are rare in pheochromocytomas and paragangliomas. Journal of Clinical Endocrinology and Metabolism 95 1274-1278. (doi:10.1210/jc.2009-2170)

Galan SR \& Kann PH 2013 Genetics and molecular pathogenesis of pheochromocytoma and paraganglioma. Clinical Endocrinology $\mathbf{7 8}$ 165-175. (doi:10.1111/cen.12071)

Gao P, Zhang H, Dinavahi R, Li F, Xiang Y, Raman V, Bhujwalla ZM, Felsher DW, Cheng L, Pevsner J et al. 2007 HIF-dependent 
antitumorigenic effect of antioxidants in vivo. Cancer Cell 12 230-238. (doi:10.1016/j.ccr.2007.08.004)

Gatenby RA \& Gillies RJ 2004 Why do cancers have high aerobic glycolysis? Nature Reviews. Cancer 4 891-899. (doi:10.1038/nrc1478)

Ghayee HK, Giubellino A, Click A, Kapur P, Christie A, Xie XJ, Martucci V, Shay JW, Souza RF \& Pacak K 2013 Phospho-mTOR is not upregulated in metastatic SDHB paragangliomas. European Journal of Clinical Investigation 43 970-977. (doi:10.1111/eci.12127)

Gill AJ, Pachter NS, Clarkson A, Tucker KM, Winship IM, Benn DE, Robinson BG \& Clifton-Bligh RJ 2011 Renal tumors and hereditary pheochromocytoma-paraganglioma syndrome type 4. New England Journal of Medicine 364 885-886. (doi:10.1056/NEJMc1012357)

Gimenez-Roqueplo AP, Favier J, Rustin P, Mourad JJ, Plouin PF, Corvol P, Rotig A \& Jeunemaitre X 2001 The R22X mutation of the SDHD gene in hereditary paraganglioma abolishes the enzymatic activity of complex II in the mitochondrial respiratory chain and activates the hypoxia pathway. American Journal of Human Genetics 69 1186-1197. (doi:10.1086/324413)

Gimenez-Roqueplo AP, Favier J, Rustin P, Rieubland C, Kerlan V, Plouin PF, Rotig A \& Jeunemaitre X 2002 Functional consequences of a SDHB gene mutation in an apparently sporadic pheochromocytoma. Journal of Clinical Endocrinology and Metabolism 87 4771-4774. (doi:10.1210/ jc.2002-020525)

Gimenez-Roqueplo AP, Favier J, Rustin P, Rieubland C, Crespin M, Nau V, Khau Van Kien P, Corvol P, Plouin PF \& Jeunemaitre X 2003 Mutations in the SDHB gene are associated with extra-adrenal and/or malignant phaeochromocytomas. Cancer Research 63 5615-5621.

Gimenez-Roqueplo AP, Dahia PL \& Robledo M 2012 An update on the genetics of paraganglioma, pheochromocytoma, and associated hereditary syndromes. Hormone and Metabolic Research 44 328-333. (doi:10.1055/s-0031-1301302)

Giubellino A, Sourbier C, Lee MJ, Scroggins B, Bullova P, Landau M, Ying W, Neckers L, Trepel JB \& Pacak K 2013 Targeting heat shock protein 90 for the treatment of malignant pheochromocytoma. PLOS ONE 8 e56083. (doi:10.1371/journal.pone.0056083)

Goffrini P, Ercolino T, Panizza E, Giache V, Cavone L, Chiarugi A, Dima V, Ferrero I \& Mannelli M 2009 Functional study in a yeast model of a novel succinate dehydrogenase subunit B gene germline missense mutation (C191Y) diagnosed in a patient affected by a glomus tumor Human Molecular Genetics 18 1860-1868. (doi:10.1093/hmg/ddp102)

Gogvadze V, Zhivotovsky B \& Orrenius S 2010 The Warburg effect and mitochondrial stability in cancer cells. Molecular Aspects of Medicine $\mathbf{3 1}$ 60-74. (doi:10.1016/j.mam.2009.12.004)

Gottlieb E \& Tomlinson IP 2005 Mitochondrial tumour suppressors: a genetic and biochemical update. Nature Reviews. Cancer 5 857-866. (doi:10.1038/nrc1737)

Guzy RD, Sharma B, Bell E, Chandel NS \& Schumacker PT 2008 Loss of the SdhB, but not the SdhA, subunit of complex II triggers reactive oxygen species-dependent hypoxia-inducible factor activation and tumorigenesis. Molecular and Cellular Biology 28 718-731. (doi:10.1128/MCB. 01338-07)

Hanahan D \& Weinberg RA 2000 The hallmarks of cancer. Cell 100 57-70. (doi:10.1016/S0092-8674(00)81683-9)

Hanahan D \& Weinberg RA 2011 Hallmarks of cancer: the next generation. Cell 144 646-674. (doi:10.1016/j.cell.2011.02.013)

Hao HX, Khalimonchuk O, Schraders M, Dephoure N, Bayley JP, Kunst H, Devilee P, Cremers CW, Schiffman JD, Bentz BG et al. 2009 SDH5, a gene required for flavination of succinate dehydrogenase, is mutated in paraganglioma. Science 325 1139-1142. (doi:10.1126/science.1175689)

Hewitson KS, McNeill LA, Elkins JM \& Schofield CJ 2003 The role of iron and 2-oxoglutarate oxygenases in signalling. Biochemical Society Transactions 31 510-515. (doi:10.1042/BST0310510)

Hobert JA, Mester JL, Moline J \& Eng C 2012 Elevated plasma succinate in PTEN, SDHB, and SDHD mutation-positive individuals. Genetics in Medicine 14 616-619. (doi:10.1038/gim.2011.63)

http://erc.endocrinology-journals.org DOI: 10.1530/ERC-13-0398
(C) 2014 Society for Endocrinology Printed in Great Britain
Holmquist-Mengelbier L, Fredlund E, Lofstedt T, Noguera R, Navarro S, Nilsson H, Pietras A, Vallon-Christersson J, Borg A, Gradin K et al. 2006 Recruitment of HIF- $1 \alpha$ and HIF- $2 \alpha$ to common target genes is differentially regulated in neuroblastoma: HIF- $2 \alpha$ promotes an aggressive phenotype. Cancer Cell 10 413-423. (doi:10.1016/j.ccr. 2006.08.026)

Horvath R, Abicht A, Holinski-Feder E, Laner A, Gempel K, Prokisch H, Lochmuller H, Klopstock T \& Jaksch M 2006 Leigh syndrome caused by mutations in the flavoprotein (Fp) subunit of succinate dehydrogenase (SDHA). Journal of Neurology, Neurosurgery, and Psychiatry 77 74-76. (doi:10.1136/jnnp.2005.067041)

Huang J \& Lemire BD 2009 Mutations in the C. elegans succinate dehydrogenase iron-sulfur subunit promote superoxide generation and premature aging. Journal of Molecular Biology 387 559-569. (doi:10.1016/j.jmb.2009.02.028)

Imperiale A, Moussallieh FM, Sebag F, Brunaud L, Barlier A, Elbayed K, Bachellier P, Goichot B, Pacak K, Namer IJ et al. 2013 A new specific succinate-glutamate metabolomic hallmark in sdhx-related paragangliomas. PLOS ONE 8 e80539. (doi:10.1371/journal.pone. 0080539)

Isaacs JS, Jung YJ, Mimnaugh EG, Martinez A, Cuttitta F \& Neckers LM 2002 Hsp90 regulates a von Hippel Lindau-independent hypoxia-inducible factor-1 $\alpha$-degradative pathway. Journal of Biological Chemistry $\mathbf{2 7} 7$ 29936-29944. (doi:10.1074/jbc.M204733200)

Isaacs JS, Jung YJ, Mole DR, Lee S, Torres-Cabala C, Chung YL, Merino M, Trepel J, Zbar B, Toro J et al. 2005 HIF overexpression correlates with biallelic loss of fumarate hydratase in renal cancer: novel role of fumarate in regulation of HIF stability. Cancer Cell 8 143-153. (doi:10.1016/j.ccr.2005.06.017)

Jiang S \& Dahia PL 2011 Minireview: The busy road to pheochromocytomas and paragangliomas has a new member, TMEM127. Endocrinology 152 2133-2140. (doi:10.1210/en.2011-0052)

Jiang H, Zhang L, Koubi D, Kuo J, Groc L, Rodriguez AI, Hunter TJ, Tang S, Lazarovici P, Gautam SC et al. 2005 Roles of Ras-Erk in apoptosis of PC12 cells induced by trophic factor withdrawal or oxidative stress. Journal of Molecular Neuroscience 25 133-140. (doi:10.1385/JMN: 25:2:133)

Jochmanova I, Yang C, Zhuang Z \& Pacak K 2013 Hypoxia-inducible factor signaling in pheochromocytoma: turning the rudder in the right direction. Journal of the National Cancer Institute 105 1270-1283. (doi:10.1093/jnci/djt201)

Jokilehto T \& Jaakkola PM 2010 The role of HIF prolyl hydroxylases in tumour growth. Journal of Cellular and Molecular Medicine 14 758-770. (doi:10.1111/j.1582-4934.2010.01030.x)

Jones RG \& Thompson CB 2009 Tumor suppressors and cell metabolism: a recipe for cancer growth. Genes and Development 23 537-548. (doi:10.1101/gad.1756509)

Kaelin WG Jr \& McKnight SL 2013 Influence of metabolism on epigenetics and disease. Cell 153 56-69. (doi:10.1016/j.cell.2013.03.004)

Kaelin WG Jr \& Ratcliffe PJ 2008 Oxygen sensing by metazoans: the central role of the HIF hydroxylase pathway. Molecular Cell 30 393-402. (doi:10.1016/j.molcel.2008.04.009)

Keith B, Johnson RS \& Simon MC 2012 HIF1 $\alpha$ and HIF2 $\alpha$ : sibling rivalry in hypoxic tumour growth and progression. Nature Reviews. Cancer 12 9-22. (doi:10.1038/nrc3183)

Khan MN, Bhattacharyya T, Andrikopoulos P, Esteban MA, Barod R, Connor T, Ashcroft M, Maxwell PH \& Kiriakidis S 2011 Factor inhibiting HIF (FIH-1) promotes renal cancer cell survival by protecting cells from HIF-1 $\alpha$-mediated apoptosis. British Journal of Cancer $\mathbf{1 0 4}$ 1151-1159. (doi:10.1038/bjc.2011.73)

Killian JK, Kim SY, Miettinen M, Smith C, Merino M, Tsokos M, Quezado M, Smith WI Jr, Jahromi MS, Xekouki P et al. 2013 Succinate dehydrogenase mutation underlies global epigenomic divergence in gastrointestinal stromal tumor. Cancer Discovery 3 648-657. (doi:10.1158/2159-8290. CD-13-0092) 
King A, Selak MA \& Gottlieb E 2006 Succinate dehydrogenase and fumarate hydratase: linking mitochondrial dysfunction and cancer. Oncogene $\mathbf{2 5}$ 4675-4682. (doi:10.1038/sj.onc.1209594)

Kluza J, Corazao-Rozas P, Touil Y, Jendoubi M, Maire C, Guerreschi P, Jonneaux A, Ballot C, Balayssac S, Valable S et al. 2012 Inactivation of the HIF-1 $\alpha /$ PDK3 signaling axis drives melanoma toward mitochondrial oxidative metabolism and potentiates the therapeutic activity of pro-oxidants. Cancer Research 72 5035-5047. (doi:10.1158/ 0008-5472.CAN-12-0979)

Koh MY, Lemos R Jr, Liu X \& Powis G 2011 The hypoxia-associated factor switches cells from HIF- $1 \alpha$ - to HIF- $2 \alpha$-dependent signaling promoting stem cell characteristics, aggressive tumor growth and invasion. Cancer Research 71 4015-4027. (doi:10.1158/0008-5472.CAN-10-4142)

Koppenol WH, Bounds PL \& Dang CV 2011 Otto Warburg's contributions to current concepts of cancer metabolism. Nature Reviews. Cancer 11 325-337. (doi:10.1038/nrc3038)

Korpershoek E, Favier J, Gaal J, Burnichon N, van Gessel B, Oudijk L, Badoual C, Gadessaud N, Venisse A, Bayley JP et al. 2011 SDHA immunohistochemistry detects germline SDHA gene mutations in apparently sporadic paragangliomas and pheochromocytomas. Journal of Clinical Endocrinology and Metabolism 96 E1472-E1476. (doi:10.1210/jc.2011-1043)

Krejci A 2012 Metabolic sensors and their interplay with cell signalling and transcription. Biochemical Society Transactions 40 311-323. (doi:10.1042/BST20110767)

Kumar A, Kant S \& Singh SM 2012 Novel molecular mechanisms of antitumor action of dichloroacetate against $\mathrm{T}$ cell lymphoma: implication of altered glucose metabolism, $\mathrm{pH}$ homeostasis and cell survival regulation. Chemico-Biological Interactions 199 29-37. (doi:10.1016/j.cbi.2012.06.005)

Ladroue C, Carcenac R, Leporrier M, Gad S, Le Hello C, Galateau-Salle F, Feunteun J, Pouyssegur J, Richard S \& Gardie B 2008 PHD2 mutation and congenital erythrocytosis with paraganglioma. New England Journal of Medicine 359 2685-2692. (doi:10.1056/NEJMoa0806277)

Lando D, Peet DJ, Gorman JJ, Whelan DA, Whitelaw ML \& Bruick RK 2002 FIH-1 is an asparaginyl hydroxylase enzyme that regulates the transcriptional activity of hypoxia-inducible factor. Genes and Development 16 1466-1471. (doi:10.1101/gad.991402)

Latif F, Duh FM, Gnarra J, Tory K, Kuzmin I, Yao M, Stackhouse T, Modi W, Geil L, Schmidt L et al. 1993 von Hippel-Lindau syndrome: cloning and identification of the plasma membrane $\mathrm{Ca}(++)$-transporting ATPase isoform 2 gene that resides in the von Hippel-Lindau gene region. Cancer Research 53 861-867.

Lee S, Nakamura E, Yang H, Wei W, Linggi MS, Sajan MP, Farese RV, Freeman RS, Carter BD, Kaelin WG Jr et al. 2005 Neuronal apoptosis linked to EglN3 prolyl hydroxylase and familial pheochromocytoma genes: developmental culling and cancer. Cancer Cell 8 155-167. (doi:10.1016/j.ccr.2005.06.015)

Lenders JW, Eisenhofer G, Mannelli M \& Pacak K 2005 Phaeochromocytoma. Lancet 366 665-675. (doi:10.1016/S0140-6736(05)67139-5)

Lendvai N, Pawlosky R, Bullova P, Eisenhofer G, Patocs A, Veech RL \& Pacak K 2014 Succinate-to-fumarate ratio as a new metabolic marker to detect the presence of SDHB/D-related paraganglioma: initial experimental and ex vivo findings. Endocrinology 155 27-32. (doi:10.1210/en.2013-1549)

Letouze E, Martinelli C, Loriot C, Burnichon N, Abermil N, Ottolenghi C, Janin M, Menara M, Nguyen AT, Benit P et al. 2013 SDH mutations establish a hypermethylator phenotype in paraganglioma. Cancer Cell 23 739-752. (doi:10.1016/j.ccr.2013.04.018)

Levine AJ \& Puzio-Kuter AM 2010 The control of the metabolic switch in cancers by oncogenes and tumor suppressor genes. Science $\mathbf{3 3 0}$ 1340-1344. (doi:10.1126/science.1193494)

Levitas A, Muhammad E, Harel G, Saada A, Caspi VC, Manor E, Beck JC, Sheffield V \& Parvari R 2010 Familial neonatal isolated cardiomyopathy caused by a mutation in the flavoprotein subunit of succinate dehydrogenase. European Journal of Human Genetics 18 1160-1165. (doi:10.1038/ejhg.2010.83)
Linehan WM \& Rouault TA 2013 Molecular pathways: fumarate hydratasedeficient kidney cancer - targeting the Warburg effect in cancer. Clinical Cancer Research 19 3345-3352. (doi:10.1158/1078-0432.CCR-13-0304)

Liu YV, Baek JH, Zhang H, Diez R, Cole RN \& Semenza GL 2007 RACK1 competes with HSP90 for binding to HIF-1 $\alpha$ and is required for O(2)independent and HSP90 inhibitor-induced degradation of HIF-1 $\alpha$. Molecular Cell 25 207-217. (doi:10.1016/j.molcel.2007.01.001)

Liu Y, Cao Y, Zhang W, Bergmeier S, Qian Y, Akbar H, Colvin R, Ding J, Tong L, Wu S et al. 2012 A small-molecule inhibitor of glucose transporter 1 downregulates glycolysis, induces cell-cycle arrest, and inhibits cancer cell growth in vitro and in vivo. Molecular Cancer Therapeutics 11 1672-1682. (doi:10.1158/1535-7163.MCT-12-0131)

Lopez-Jimenez E, Gomez-Lopez G, Leandro-Garcia LJ, Munoz I, Schiavi F, Montero-Conde C, de Cubas AA, Ramires R, Landa I, Leskela S et al. 2010 Research resource: Transcriptional profiling reveals different pseudohypoxic signatures in SDHB and VHL-related pheochromocytomas. Molecular Endocrinology 24 2382-2391. (doi:10.1210/ me.2010-0256)

Lorenzo FR, Yang C, Ng Tang Fui M, Vankayalapati H, Zhuang Z, Huynh T, Grossmann M, Pacak K \& Prchal JT 2012 A novel EPAS1/HIF2A germline mutation in a congenital polycythemia with paraganglioma. Journal of Molecular Medicine 91 507-512. (doi:10.1007/s00109-0120967-z)

Luo W \& Semenza GL 2011 Pyruvate kinase M2 regulates glucose metabolism by functioning as a coactivator for hypoxia-inducible factor 1 in cancer cells. Oncotarget 2 551-556.

Luo W \& Semenza GL 2012 Emerging roles of PKM2 in cell metabolism and cancer progression. Trends in Endocrinology and Metabolism 23 560-566. (doi:10.1016/j.tem.2012.06.010)

Luo W, Hu H, Chang R, Zhong J, Knabel M, O'Meally R, Cole RN, Pandey A \& Semenza GL 2011 Pyruvate kinase M2 is a PHD3-stimulated coactivator for hypoxia-inducible factor 1. Cell 145 732-744. (doi:10.1016/j.cell.2011.03.054)

MacKenzie ED, Selak MA, Tennant DA, Payne LJ, Crosby S, Frederiksen CM, Watson DG \& Gottlieb E 2007 Cell-permeating $\alpha$-ketoglutarate derivatives alleviate pseudohypoxia in succinate dehydrogenasedeficient cells. Molecular and Cellular Biology 27 3282-3289. (doi:10.1128/MCB.01927-06)

Mahalingam D, Swords R, Carew JS, Nawrocki ST, Bhalla K \& Giles FJ 2009 Targeting HSP90 for cancer therapy. British Journal of Cancer $\mathbf{1 0 0}$ 1523-1529. (doi:10.1038/sj.bjc.6605066)

Maher ER \& Eng C 2002 The pressure rises: update on the genetics of phaeochromocytoma. Human Molecular Genetics 11 2347-2354. (doi:10.1093/hmg/11.20.2347)

Mahon PC, Hirota K \& Semenza GL 2001 FIH-1: a novel protein that interacts with HIF- $1 \alpha$ and VHL to mediate repression of HIF-1 transcriptional activity. Genes and Development 15 2675-2686. (doi:10.1101/gad.924501)

Majmundar AJ, Wong WJ \& Simon MC 2010 Hypoxia-inducible factors and the response to hypoxic stress. Molecular Cell 40 294-309. (doi:10.1016/j.molcel.2010.09.022)

Mathupala SP, Ko YH \& Pedersen PL 2009 Hexokinase-2 bound to mitochondria: cancer's stygian link to the "Warburg Effect" and a pivotal target for effective therapy. Seminars in Cancer Biology 19 17-24. (doi:10.1016/j.semcancer.2008.11.006)

Matsushita K, Uchida K, Saigusa S, Ide S, Hashimoto K, Koike Y, Otake K, Inoue M, Tanaka K \& Kusunoki M 2012 Glycolysis inhibitors as a potential therapeutic option to treat aggressive neuroblastoma expressing GLUT1. Journal of Pediatric Surgery 47 1323-1330. (doi:10.1016/j.jpedsurg.2011.12.007)

Meng M, Chen S, Lao T, Liang D \& Sang N 2010 Nitrogen anabolism underlies the importance of glutaminolysis in proliferating cells. Cell Cycle 9 3921-3932. (doi:10.4161/cc.9.19.13139)

Michelakis ED, Webster L \& Mackey JR 2008 Dichloroacetate (DCA) as a potential metabolic-targeting therapy for cancer. British Journal of Cancer 99 989-994. (doi:10.1038/sj.bjc.6604554) 
Mole DR, Blancher C, Copley RR, Pollard PJ, Gleadle JM, Ragoussis J \& Ratcliffe PJ 2009 Genome-wide association of hypoxia-inducible factor (HIF)- $1 \alpha$ and HIF- $2 \alpha$ DNA binding with expression profiling of hypoxiainducible transcripts. Journal of Biological Chemistry 284 16767-16775. (doi:10.1074/jbc.M901790200)

Mulligan LM, Kwok JB, Healey CS, Elsdon MJ, Eng C, Gardner E, Love DR, Mole SE, Moore JK, Papi L et al. 1993 Germ-line mutations of the RET proto-oncogene in multiple endocrine neoplasia type 2A. Nature 363 458-460. (doi:10.1038/363458a0)

Nakajima EC \& Van Houten B 2013 Metabolic symbiosis in cancer: refocusing the Warburg lens. Molecular Carcinogenesis 52 329-337. (doi:10.1002/mc.21863)

van Nederveen FH, Gaal J, Favier J, Korpershoek E, Oldenburg RA, de Bruyn EM, Sleddens HF, Derkx P, Riviere J, Dannenberg H et al. 2009 An immunohistochemical procedure to detect patients with paraganglioma and phaeochromocytoma with germline SDHB, SDHC, or SDHD gene mutations: a retrospective and prospective analysis. Lancet Oncology 10 764-771. (doi:10.1016/S1470-2045 (09)70164-0)

Nepal M, Gong YD, Park YR \& Soh Y 2011 An activator of PHD2, KRH102140, decreases angiogenesis via inhibition of HIF-1 $\alpha$. Cell Biochemistry and Function 29 126-134. (doi:10.1002/cbf.1732)

Neumann HP, Bausch B, McWhinney SR, Bender BU, Gimm O, Franke G, Schipper J, Klisch J, Altehoefer C, Zerres K et al. 2002 Germ-line mutations in nonsyndromic pheochromocytoma. New England Journal of Medicine 346 1459-1466. (doi:10.1056/NEJMoa020152)

Ni Y \& Eng C 2012 Vitamin E protects against lipid peroxidation and rescues tumorigenic phenotypes in Cowden/Cowden-like patientderived lymphoblast cells with germline SDHx variants. Clinical Cancer Research 18 4954-4961. (doi:10.1158/1078-0432.CCR-12-1055)

Ni Y, Zbuk KM, Sadler T, Patocs A, Lobo G, Edelman E, Platzer P, Orloff MS, Waite KA \& Eng C 2008 Germline mutations and variants in the succinate dehydrogenase genes in Cowden and Cowden-like syndromes. American Journal of Human Genetics 83 261-268. (doi:10.1016/ j.ajhg.2008.07.011)

Ni Y, He X, Chen J, Moline J, Mester J, Orloff MS, Ringel MD \& Eng C 2012 Germline SDHx variants modify breast and thyroid cancer risks in Cowden and Cowden-like syndrome via FAD/NAD-dependant destabilization of p53. Human Molecular Genetics 21 300-310. (doi:10.1093/hmg/ddr459)

Niemann S \& Muller U 2000 Mutations in SDHC cause autosomal dominant paraganglioma, type 3. Nature Genetics 26 268-270. (doi:10.1038/81551)

Nilsson H, Jogi A, Beckman S, Harris AL, Poellinger L \& Pahlman S 2005 HIF- $2 \alpha$ expression in human fetal paraganglia and neuroblastoma: relation to sympathetic differentiation, glucose deficiency, and hypoxia. Experimental Cell Research 303 447-456. (doi:10.1016/j.yexcr. 2004.10.003)

Nolting S \& Grossman AB 2012 Signaling pathways in pheochromocytomas and paragangliomas: prospects for future therapies. Endocrine Pathology 23 21-33. (doi:10.1007/s12022-012-9199-6)

Nolting S, Garcia E, Alusi G, Giubellino A, Pacak K, Korbonits M \& Grossman AB 2012 Combined blockade of signalling pathways shows marked anti-tumour potential in phaeochromocytoma cell lines. Journal of Molecular Endocrinology 49 79-96. (doi:10.1530/JME-12-0028)

Northcott PA, Shih DJ, Remke M, Cho YJ, Kool M, Hawkins C, Eberhart CG, Dubuc A, Guettouche T, Cardentey Y et al. 2012 Rapid, reliable, and reproducible molecular sub-grouping of clinical medulloblastoma samples. Acta Neuropathologica 123 615-626. (doi:10.1007/s00401011-0899-7)

Osthus RC, Shim H, Kim S, Li Q, Reddy R, Mukherjee M, Xu Y, Wonsey D, Lee LA \& Dang CV 2000 Deregulation of glucose transporter 1 and glycolytic gene expression by c-Myc. Journal of Biological Chemistry $\mathbf{2 7 5}$ 21797-21800. (doi:10.1074/jbc.C000023200)

Owens KM, Aykin-Burns N, Dayal D, Coleman MC, Domann FE \& Spitz DR 2012 Genomic instability induced by mutant succinate dehydrogenase subunit D (SDHD) is mediated by $\mathrm{O}_{2}(-\cdot)$ and $\mathrm{H}_{2} \mathrm{O}_{2}$. Free Radical Biology \& Medicine 52 160-166. (doi:10.1016/j.freeradbiomed.2011.10.435)

Pan JS, Hong MZ \& Ren JL 2009 Reactive oxygen species: a double-edged sword in oncogenesis. World Journal of Gastroenterology 15 1702-1707. (doi:10.3748/wjg.15.1702)

Papaspyrou K, Mewes T, Rossmann H, Fottner C, Schneider-Raetzke B, Bartsch O, Schreckenberger M, Lackner KJ, Amedee RG \& Mann WJ 2012 Head and neck paragangliomas: Report of 175 patients (1989-2010). Head \& Neck 34 632-637. (doi:10.1002/hed.21790)

Parfait B, Chretien D, Rotig A, Marsac C, Munnich A \& Rustin P 2000 Compound heterozygous mutations in the flavoprotein gene of the respiratory chain complex II in a patient with Leigh syndrome. Human Genetics 106 236-243. (doi:10.1007/s004390051033)

Parks SK, Chiche J \& Pouyssegur J 2013 Disrupting proton dynamics and energy metabolism for cancer therapy. Nature Reviews. Cancer 13 611-623. (doi:10.1038/nrc3579)

Patel SA \& Simon MC 2008 Biology of hypoxia-inducible factor- $2 \alpha$ in development and disease. Cell Death and Differentiation 15 628-634. (doi:10.1038/cdd.2008.17)

Pedersen PL 2012 3-Bromopyruvate (3BP) a fast acting, promising, powerful, specific, and effective "small molecule" anti-cancer agent taken from labside to bedside: introduction to a special issue. Journal of Bioenergetics and Biomembranes 44 1-6. (doi:10.1007/ s10863-012-9425-4)

Pollard PJ, Briere JJ, Alam NA, Barwell J, Barclay E, Wortham NC, Hunt T, Mitchell M, Olpin S, Moat SJ et al. 2005 Accumulation of Krebs cycle intermediates and over-expression of HIF1 $\alpha$ in tumours which result from germline FH and SDH mutations. Human Molecular Genetics 14 2231-2239. (doi:10.1093/hmg/ddi227)

Pollard PJ, El-Bahrawy M, Poulsom R, Elia G, Killick P, Kelly G, Hunt T, Jeffery R, Seedhar P, Barwell J et al. 2006 Expression of HIF-1 $\alpha$, HIF- $2 \alpha$ (EPAS1), and their target genes in paraganglioma and pheochromocytoma with VHL and SDH mutations. Journal of Clinical Endocrinology and Metabolism 91 4593-4598. (doi:10.1210/jc.2006-0920)

Powers JF, Evinger MJ, Zhi J, Picard KL \& Tischler AS 2007 Pheochromocytomas in Nf1 knockout mice express a neural progenitor gene expression profile. Neuroscience 147 928-937. (doi:10.1016/j.neuroscience.2007.05.008)

Qin Y, Yao L, King EE, Buddavarapu K, Lenci RE, Chocron ES, Lechleiter JD, Sass M, Aronin N, Schiavi F et al. 2010 Germline mutations in TMEM127 confer susceptibility to pheochromocytoma. Nature Genetics 42 229-233. (doi:10.1038/ng.533)

Rankin EB, Biju MP, Liu Q, Unger TL, Rha J, Johnson RS, Simon MC, Keith B \& Haase VH 2007 Hypoxia-inducible factor-2 (HIF-2) regulates hepatic erythropoietin in vivo. Journal of Clinical Investigation 117 1068-1077. (doi:10.1172/JCI30117)

Rao JU, Engelke UF, Rodenburg RJ, Wevers RA, Pacak K, Eisenhofer G, Qin N, Kusters B, Goudswaard AG, Lenders JW et al. 2013 Genotype-specific abnormalities in mitochondrial function associate with distinct profiles of energy metabolism and catecholamine content in pheochromocytoma and paraganglioma. Clinical Cancer Research 193787-3795. (doi:10.1158/ 1078-0432.CCR-12-3922)

Rapizzi E, Ercolino T, Canu L, Giache V, Francalanci M, Pratesi C, Valeri A \& Mannelli M 2012 Mitochondrial function and content in pheochromocytoma/paraganglioma of succinate dehydrogenase mutation carriers. Endocrine-Related Cancer 19 261-269. (doi:10.1530/ERC11-0263)

Rogers JL, Bayeh L, Scheuermann TH, Longgood J, Key J, Naidoo J, Melito L, Shokri C, Frantz DE, Bruick RK et al. 2013 Development of inhibitors of the PAS-B domain of the HIF- $2 \alpha$ transcription factor. Journal of Medicinal Chemistry 56 1739-1747. (doi:10.1021/jm301847z)

Rustin P, Munnich A \& Rotig A 2002 Succinate dehydrogenase and human diseases: new insights into a well-known enzyme. European Journal of Human Genetics 10 289-291. (doi:10.1038/sj.ejhg.5200793)

Sandgren J, Diaz de Stahl T, Andersson R, Menzel U, Piotrowski A, Nord H, Backdahl M, Kiss NB, Brauckhoff M, Komorowski J et al. 2010 Recurrent 
genomic alterations in benign and malignant pheochromocytomas and paragangliomas revealed by whole-genome array comparative genomic hybridization analysis. Endocrine-Related Cancer 17 561-579. (doi:10.1677/ERC-09-0310)

Schiavi F, Boedeker CC, Bausch B, Peczkowska M, Gomez CF, Strassburg T, Pawlu C, Buchta M, Salzmann M, Hoffmann MM et al. 2005 Predictors and prevalence of paraganglioma syndrome associated with mutations of the SDHC gene. Journal of the American Medical Association 294 2057-2063. (doi:10.1001/jama.294.16.2057)

Schlisio S, Kenchappa RS, Vredeveld LC, George RE, Stewart R, Greulich H, Shahriari K, Nguyen NV, Pigny P, Dahia PL et al. 2008 The kinesin KIF1B $\beta$ acts downstream from EglN3 to induce apoptosis and is a potential 1p36 tumor suppressor. Genes and Development 22 884-893. (doi:10.1101/gad.1648608)

Selak MA, Armour SM, MacKenzie ED, Boulahbel H, Watson DG, Mansfield KD, Pan Y, Simon MC, Thompson CB \& Gottlieb E 2005 Succinate links TCA cycle dysfunction to oncogenesis by inhibiting HIF- $\alpha$ prolyl hydroxylase. Cancer Cell 7 77-85. (doi:10.1016/j.ccr. 2004.11.022)

Semenza G 2002a Signal transduction to hypoxia-inducible factor 1 . Biochemical Pharmacology 64 993-998. (doi:10.1016/S00062952(02)01168-1)

Semenza GL $2002 b$ HIF-1 and tumor progression: pathophysiology and therapeutics. Trends in Molecular Medicine 8 S62-S67. (doi:10.1016/ S1471-4914(02)02317-1)

Semenza GL 2007 Evaluation of HIF-1 inhibitors as anticancer agents. Drug Discovery Today 12 853-859. (doi:10.1016/j.drudis.2007.08.006)

Semenza GL 2010 Defining the role of hypoxia-inducible factor 1 in cancer biology and therapeutics. Oncogene 29 625-634. (doi:10.1038/onc. 2009.441)

Semenza GL 2011 Oxygen sensing, homeostasis, and disease. New England Journal of Medicine 365 537-547. (doi:10.1056/NEJMra1011165)

Semenza GL 2012 Hypoxia-inducible factors: mediators of cancer progression and targets for cancer therapy. Trends in Pharmacological Sciences 33 207-214. (doi:10.1016/j.tips.2012.01.005)

Shah U, Giubellino A \& Pacak K 2012 Pheochromocytoma: implications in tumorigenesis and the actual management. Minerva Endocrinologica 37 141-156.

Singh RP, Franke K, Kalucka J, Mamlouk S, Muschter A, Gembarska A, Grinenko T, Willam C, Naumann R, Anastassiadis K et al. 2013 HIF prolyl hydroxylase 2 (PHD2) is a critical regulator of hematopoietic stem cell maintenance during steady-state and stress. Blood $\mathbf{1 2 1}$ 5158-5166. (doi:10.1182/blood-2012-12-471185)

Slane BG, Aykin-Burns N, Smith BJ, Kalen AL, Goswami PC, Domann FE \& Spitz DR 2006 Mutation of succinate dehydrogenase subunit $C$ results in increased $\mathrm{O}_{2} \cdot-$, oxidative stress, and genomic instability. Cancer Research 66 7615-7620. (doi:10.1158/0008-5472.CAN-06-0833)

Soga T 2013 Cancer metabolism: key players in metabolic reprogramming. Cancer Science 104 275-281. (doi:10.1111/cas.12085)

Spitz DR 2011 Metabolic oxidative stress and low dose radiation responses: are mitochondria involved. Health Physics 100 295. (doi:10.1097/HP. Ob013e31820840aa)

Sun L, Bartlam M, Liu Y, Pang H \& Rao Z 2005a Crystal structure of the pyridoxal-5' -phosphate-dependent serine dehydratase from human liver. Protein Science 14 791-798. (doi:10.1110/ps.041179105)

Sun F, Huo X, Zhai Y, Wang A, Xu J, Su D, Bartlam M \& Rao Z 2005b Crystal structure of mitochondrial respiratory membrane protein complex II. Cell 121 1043-1057. (doi:10.1016/j.cell.2005.05.025)

Sutendra G \& Michelakis ED 2013 Pyruvate dehydrogenase kinase as a novel therapeutic target in oncology. Frontiers in Oncology 338. (doi:10.3389/fonc.2013.00038)

Sutendra G, Dromparis P, Kinnaird A, Stenson TH, Haromy A, Parker JM, McMurtry MS \& Michelakis ED 2013 Mitochondrial activation by inhibition of PDKII suppresses HIF1a signaling and angiogenesis in cancer. Oncogene 32 1638-1650. (doi:10.1038/onc.2012.198)
Taieb D, Sebag F, Barlier A, Tessonnier L, Palazzo FF, Morange I, Niccoli-Sire P, Fakhry N, De Micco C, Cammilleri S et al. $2009{ }^{18}$ F-FDG avidity of pheochromocytomas and paragangliomas: a new molecular imaging signature? Journal of Nuclear Medicine 50 711-717. (doi:10.2967/jnumed. 108.060731)

Tannahill GM, Curtis AM, AdamikJ, Palsson-McDermott EM, McGettrick AF, Goel G, Frezza C, Bernard NJ, Kelly B, Foley NH et al. 2013 Succinate is an inflammatory signal that induces IL-1 $\beta$ through HIF-1 $\alpha$. Nature 496 238-242. (doi:10.1038/nature11986)

Tennant DA \& Gottlieb E 2010 HIF prolyl hydroxylase-3 mediates $\alpha$-ketoglutarate-induced apoptosis and tumor suppression. Journal of Molecular Medicine 88 839-849. (doi:10.1007/s00109-010-0627-0)

Tennant DA, Frezza C, MacKenzie ED, Nguyen QD, Zheng L, Selak MA, Roberts DL, Dive C, Watson DG, Aboagye EO et al. 2009 Reactivating HIF prolyl hydroxylases under hypoxia results in metabolic catastrophe and cell death. Oncogene 28 4009-4021. (doi:10.1038/onc.2009.250)

Tian H, Hammer RE, Matsumoto AM, Russell DW \& McKnight SL 1998 The hypoxia-responsive transcription factor EPAS1 is essential for catecholamine homeostasis and protection against heart failure during embryonic development. Genes and Development 12 3320-3324. (doi:10.1101/gad.12.21.3320)

Timmers HJ, Kozupa A, Eisenhofer G, Raygada M, Adams KT, Solis D, Lenders JW \& Pacak K 2007 Clinical presentations, biochemical phenotypes, and genotype-phenotype correlations in patients with succinate dehydrogenase subunit B-associated pheochromocytomas and paragangliomas. Journal of Clinical Endocrinology and Metabolism 92 779-786. (doi:10.1210/jc.2006-2315)

Timmers HJ, Gimenez-Roqueplo AP, Mannelli M \& Pacak K 2009a Clinical aspects of SDHx-related pheochromocytoma and paraganglioma. Endocrine-Related Cancer 16 391-400. (doi:10.1677/ERC-08-0284)

Timmers HJ, Chen CC, Carrasquillo JA, Whatley M, Ling A, Havekes B, Eisenhofer G, Martiniova L, Adams KT \& Pacak K 2009b Comparison of ${ }^{18} \mathrm{~F}$-fluoro-L-DOPA, ${ }^{18} \mathrm{~F}$-fluoro-deoxyglucose, and ${ }^{18} \mathrm{~F}$-fluorodopamine PET and 123I-MIBG scintigraphy in the localization of pheochromocytoma and paraganglioma. Journal of Clinical Endocrinology and Metabolism 94 4757-4767. (doi:10.1210/jc.2009-1248)

Timmers HJ, Chen CC, Carrasquillo JA, Whatley M, Ling A, Eisenhofer G, King KS, Rao JU, Wesley RA, Adams KT et al. 2012 Staging and functional characterization of pheochromocytoma and paraganglioma by ${ }^{18} \mathrm{~F}$-fluorodeoxyglucose $\left({ }^{18} \mathrm{~F}\right.$-FDG) positron emission tomography. Journal of the National Cancer Institute 104 700-708. (doi:10.1093/ jnci/djs188)

Toledo RA, Qin Y, Srikantan S, Morales NP, Li Q, Deng Y, Kim SW, Pereira MA, Toledo SP, Su X et al. 2013 In vivo and in vitro oncogenic effects of HIF2A mutations in pheochromocytomas and paragangliomas. EndocrineRelated Cancer 20 349-359. (doi:10.1530/ERC-13-0101)

Vegran F, Boidot R, Michiels C, Sonveaux P \& Feron O 2011 Lactate influx through the endothelial cell monocarboxylate transporter MCT1 supports an NF- $\kappa \mathrm{B} / \mathrm{IL}-8$ pathway that drives tumor angiogenesis. Cancer Research 71 2550-2560. (doi:10.1158/0008-5472.CAN-10-2828)

Vicha A, Musil Z \& Pacak K 2013 Genetics of pheochromocytoma and paraganglioma syndromes: new advances and future treatment options. Current Opinion in Endocrinology, Diabetes, and Obesity 20 186-191. (doi:10.1097/MED.0b013e32835fcc45)

Viskochil D, Buchberg AM, Xu G, Cawthon RM, Stevens J, Wolff RK, Culver M, Carey JC, Copeland NG, Jenkins NA et al. 1990 Deletions and a translocation interrupt a cloned gene at the neurofibromatosis type 1 locus. Cell 62 187-192. (doi:10.1016/0092-8674(90)90252-A)

Vogelstein B \& Kinzler KW 2004 Cancer genes and the pathways they control. Nature Medicine 10 789-799. (doi:10.1038/nm1087)

Walenta S \& Mueller-Klieser WF 2004 Lactate: mirror and motor of tumor malignancy. Seminars in Radiation Oncology 14 267-274. (doi:10.1016/ j.semradonc.2004.04.004)

Warburg O 1956 On the origin of cancer cells. Science 123 309-314. (doi:10.1126/science.123.3191.309) http://erc.endocrinology-journals.org

DOI: 10.1530/ERC-13-0398
(C) 2014 Society for Endocrinology Printed in Great Britain 
Warburg O, Wind F \& Negelein E 1926 Über den Stoffwechsel der Tumoren in Körper. Klinische Wochenschrift 5 829-832. (doi:10.1007/ BF01726240)

Weber A, Hoffmann MM, Neumann HP \& Erlic Z 2012 Somatic mutation analysis of the SDHB, SDHC, SDHD, and RET genes in the clinical assessment of sporadic and hereditary pheochromocytoma. Hormones \& Cancer 3 187-192. (doi:10.1007/s12672-012-0113-y)

Welsh SJ, Williams RR, Birmingham A, Newman DJ, Kirkpatrick DL \& Powis G 2003 The thioredoxin redox inhibitors 1-methylpropyl 2-imidazolyl disulfide and pleurotin inhibit hypoxia-induced factor $1 \alpha$ and vascular endothelial growth factor formation. Molecular Cancer Therapeutics 2 235-243.

Welsh S, Williams R, Kirkpatrick L, Paine-Murrieta G \& Powis G 2004 Antitumor activity and pharmacodynamic properties of PX-478, an inhibitor of hypoxia-inducible factor- $1 \alpha$. Molecular Cancer Therapeutics 3 233-244.

Xiao M, Yang H, Xu W, Ma S, Lin H, Zhu H, Liu L, Liu Y, Yang C, Xu Y et al. 2012 Inhibition of $\alpha$-KG-dependent histone and DNA demethylases by fumarate and succinate that are accumulated in mutations of $\mathrm{FH}$ and SDH tumor suppressors. Genes and Development 26 1326-1338. (doi:10.1101/gad.191056.112)

Xie J, Wang BS, Yu DH, Lu Q, Ma J, Qi H, Fang C \& Chen HZ 2011 Dichloroacetate shifts the metabolism from glycolysis to glucose oxidation and exhibits synergistic growth inhibition with cisplatin in HeLa cells. International Journal of Oncology 38 409-417.

Yang C, Matro JC, Huntoon KM, Ye DY, Huynh TT, Fliedner SMJ, Breza J, Zhuang Z \& Pacak K 2012 Missense mutations in human SDHB gene increase protein degradation without altering intrinsic enzymatic function. FASEB Journal 26 4506-4516. (doi:10.1096/ fj.12-210146)

Yankovskaya V, Horsefield R, Tornroth S, Luna-Chavez C, Miyoshi H, Leger C, Byrne B, Cecchini G \& Iwata S 2003 Architecture of succinate dehydrogenase and reactive oxygen species generation. Science 299 700-704. (doi:10.1126/science.1079605)
Yao L, Schiavi F, Cascon A, Qin Y, Inglada-Perez L, King EE, Toledo RA, Ercolino T, Rapizzi E, Ricketts CJ et al. 2010 Spectrum and prevalence of FP/TMEM127 gene mutations in pheochromocytomas and paragangliomas. Journal of the American Medical Association 304 2611-2619. (doi:10.1001/jama.2010.1830)

Yeh IT, Lenci RE, Qin Y, Buddavarapu K, Ligon AH, Leteurtre E, Do Cao C, Cardot-Bauters C, Pigny P \& Dahia PL 2008 A germline mutation of the KIF1B $\beta$ gene on 1 p36 in a family with neural and nonneural tumors. Human Genetics 124 279-285. (doi:10.1007/s00439-008-0553-1)

Yu SJ, Yoon JH, Yang JI, Cho EJ, Kwak MS, Jang ES, Lee JH, Kim YJ, Lee HS \& Kim CY 2012 Enhancement of hexokinase II inhibitor-induced apoptosis in hepatocellular carcinoma cells via augmenting ER stress and anti-angiogenesis by protein disulfide isomerase inhibition. Journal of Bioenergetics and Biomembranes 44 101-115. (doi:10.1007/ s10863-012-9416-5)

Yuneva M 2008 Finding an "Achilles' heel" of cancer: the role of glucose and glutamine metabolism in the survival of transformed cells. Cell Cycle 7 2083-2089. (doi:10.4161/cc.7.14.6256)

Zelinka T, Timmers HJ, Kozupa A, Chen CC, Carrasquillo JA, Reynolds JC, Ling A, Eisenhofer G, Lazurova I, Adams KT et al. 2008 Role of positron emission tomography and bone scintigraphy in the evaluation of bone involvement in metastatic pheochromocytoma and paraganglioma: specific implications for succinate dehydrogenase enzyme subunit B gene mutations. Endocrine-Related Cancer 15 311-323. (doi:10.1677/ ERC-07-0217)

Zhang C, Moore LM, Li X, Yung WK \& Zhang W 2013 IDH1/2 mutations target a key hallmark of cancer by deregulating cellular metabolism in glioma. Neurooncology 15 1114-1126. (doi:10.1093/ neuonc/not087)

Zhuang Z, Yang C, Lorenzo F, Merino M, Fojo T, Kebebew E, Popovic V, Stratakis CA, Prchal JT \& Pacak K 2012 Somatic HIF2A gain-of-function mutations in paraganglioma with polycythemia. New England Journal of Medicine 367 922-930. (doi:10.1056/NEJMoa1205119)

Received in final form 31 January 2014

Accepted 5 February 2014

Made available online as an Accepted Preprint

5 February 2014
(C) 2014 Society for Endocrinology Printed in Great Britain 